\title{
Direct recognition of hepatocyte- expressed MHC class I alloantigens is required for tolerance induction
}

\author{
Moumita Paul-Heng, ${ }^{1}$ Mario Leong, ${ }^{1}$ Eithne Cunningham, ${ }^{1}$ Daniel L. J. Bunker, ${ }^{1}$ \\ Katherine Bremner, ${ }^{2}$ Zane Wang, ${ }^{1}$ Chuanmin Wang, ${ }^{1}$ Szun Szun Tay, ${ }^{2}$ Claire McGuffog, ${ }^{2}$ \\ Grant J. Logan, ${ }^{3}$ Ian E. Alexander,, ${ }^{3,4}$ Min Hu, ${ }^{5}$ Stephen I. Alexander, ${ }^{6}$ Tim D. Sparwasser, \\ Patrick Bertolino, ${ }^{2}$ David G. Bowen, ${ }^{1,2}$ G. Alex Bishop, ${ }^{1}$ and Alexandra Sharland ${ }^{1}$ \\ 'Transplantation Immunobiology Group, University of Sydney Central Clinical School, Charles Perkins Centre, Faculty of \\ Medicine and Health, Sydney, NSW, Australia. ' Liver Immunology Group and AW Morrow Gastroenterology and Liver \\ Centre, The University of Sydney and Royal Prince Alfred Hospital, Sydney, NSW, Australia. ${ }^{3}$ Cene Therapy Research \\ Unit, Children's Medical Research Institute, The University of Sydney, Faculty of Medicine and Health and Sydney \\ Children's Hospitals Network, Westmead, Australia. ${ }^{4} T$ The University of Sydney, Sydney Medical School, Discipline of \\ Child and Adolescent Health, Westmead, Australia. ${ }^{5}$ Centre for Transplant and Renal Research, Westmead Institute \\ for Medical Research, The University of Sydney, Westmead, NSW, Australia. 'Centre for Kidney Research, Children's \\ Hospital at Westmead, The University of Sydney, NSW, Australia. Institute of Infection Immunology, Twincore, Centre for \\ Experimental and Clinical Infection Research, Hannover Medical School, Germany.
}

License: This work is licensed under the Creative Commons Attribution 4.0 International License. To view a copy of this license, visit http:// creativecommons.org/licenses/by/4.0/

Authorship note: MPH and ML contributed equally to this work.

Conflict of interest: $\mathrm{EC}$ has been employed in a medical-scientific liaison role by Shire Pharmaceuticals since April 2016. This position is not connected to the research work described in this article.

Submitted: September 18, 2017

Accepted: June 28, 2018

Published: August 9, 2018

Reference information: JCI Insight. 2018;3(15):e97500 https://doi.org/10.1172/jci. insight. 97500 .
Adeno-associated viral vector-mediated (AAV-mediated) expression of allogeneic major histocompatibility complex class I (MHC class I) in recipient liver induces donor-specific tolerance in mouse skin transplant models in which a class I allele $\left(\mathrm{H}-2 \mathrm{~K}^{\mathrm{b}}\right.$ or $\left.\mathrm{H}-2 \mathrm{~K}^{\mathrm{d}}\right)$ is mismatched between donor and recipient. Tolerance can be induced in mice primed by prior rejection of a donor-strain skin graft, as well as in naive recipients. Allogeneic MHC class I may be recognized by recipient T cells as an intact molecule (direct recognition) or may be processed and presented as an allogeneic peptide in the context of self-MHC (indirect recognition). The relative contributions of direct and indirect allorecognition to tolerance induction in this setting are unknown. Using hepatocytespecific AAV vectors encoding WT allogeneic MHC class I molecules, or class I molecules containing a point mutation (D227K) that impedes direct recognition of intact allogeneic MHC class I by CD8 ${ }^{+} \mathrm{T}$ cells without hampering the presentation of processed peptides derived from allogeneic MHC class I, we show here that tolerance induction depends upon recognition of intact MHC class I. Indirect recognition alone yielded a modest prolongation of subsequent skin graft survival, attributable to the generation of $\mathrm{CD4}^{+}$Tregs, but it was not sufficient to induce tolerance.

\section{Introduction}

Transplantation is a life-saving treatment for end-stage organ failure, but for the majority of recipients, ongoing graft function relies on long-term maintenance immunosuppression, with the attendant complications of cancer, opportunistic infection, and metabolic derangement (1). Achievement of alloantigen-specific tolerance would alleviate the burden of immunosuppressive therapy, improving both graft and patient outcomes.

The liver is a tolerogenic environment. Spontaneous liver transplant tolerance is observed in both small and large animal models (2-4), and up to $20 \%$ of clinical liver transplant recipients may be successfully weaned from all immunosuppression (5). Primary viral infections of hepatocytes frequently persist (6-8), while tolerance of various transgene products expressed in the liver following transduction of hepatocytes with viral vectors has also been documented (9-13). Recombinant vectors based on the Adeno-associated virus (AAV) are promising candidates for liver-directed gene transfer - not only for the treatment of monogenic liver diseases $(14,15)$, but also for the induction of systemic, antigen-specific tolerance (16), an application that may be of great benefit to transplant recipients. AAV vectors have an excellent safety profile and are currently being evaluated in a range of clinical trials (17). Recent advances in AAV vector biology have yielded vectors with greatly increased transduction efficiency for human hepatocytes (18). We have previously 
demonstrated that AAV-mediated expression of donor major histocompatibility complex class I (MHC class $\mathrm{I} ; \mathrm{H}-2 \mathrm{~K}^{\mathrm{b}}$ ) in $\mathrm{MHC}$-mismatched recipient hepatocytes induces donor-specific tolerance in a mouse skin transplant model. Tolerance can be induced in mice primed by prior rejection of a donor-strain skin graft, as well as in naive recipients (19). The ability to overcome preexisting immunity is particularly relevant to the clinical setting, where heterologous immunity presents a barrier to transplant tolerance induction (20). To progress toward clinical translation of this strategy, it is imperative to determine whether tolerance induction can be generalized to other mismatched alleles and MHC backgrounds, and to understand more about the underlying mechanisms; in the process, we may also come to understand more about allorecognition in spontaneous liver transplant tolerance.

Allogeneic MHC class I may be recognized by recipient T cells as an intact molecule on the surface of the antigen-presenting cell (APC) (direct recognition) or may be processed and presented as allogeneic peptide fragments in the context of self-MHC molecules (indirect recognition), reviewed in ref. 21. Antigen presentation by several populations of liver-resident cells including hepatocytes (22), Kupffer cells (12), DCs (23-26), and sinusoidal endothelial cells (27) has been reported to induce tolerance. Hepatic stellate cells may themselves act as $\operatorname{APC}(28,29)$ or may regulate the outcome of antigen presentation by other cell types $(30,31)$. The structure of the hepatic microcirculation facilitates interactions between circulating naive $\mathrm{T}$ cells and hepatocytes (32), promoting tolerance induction. Recognition of intact allogeneic MHC class I by alloreactive $\mathrm{CD} 8^{+} \mathrm{T}$ cells depends upon engagement of the CD8 coreceptor by residues present in the acidic loop of the $\alpha 3$ domain of MHC class I $(33,34)$. Accordingly, recognition of an intact allogeneic MHC class I transgene product can be impeded by introducing a point mutation from a conserved aspartic acid to lysine at position 227 of the class I heavy chain (D227K) $(35,36)$. The D227K mutation does not impair presentation of processed MHC class I peptides. In this study, we have utilized AAV vectors encoding the D227K mutant or WT allogeneic MHC class I molecules $\left(\mathrm{H}-2 \mathrm{~K}^{\mathrm{b}}\right.$ or $\left.\mathrm{H}-2 \mathrm{~K}^{\mathrm{d}}\right)$ to determine the relative contributions of direct and indirect allorecognition to transplant tolerance induction.

\section{Results}

$A A V$-mediated gene transfer of $H-2 K^{d}$ to $C 57 B L / 6$ recipient hepatocytes induces tolerance to $H$ - $2 K^{d}$-bearing skin grafts. We have previously shown that expression of $\mathrm{H}-2 \mathrm{~K}^{\mathrm{b}}$ in the recipient liver induces donor-specific tolerance in a mouse skin transplant model where $\mathrm{H}-2 \mathrm{~K}^{\mathrm{b}}$ is mismatched between the donor and the B10.BR $\left(\mathrm{H}-2^{\mathrm{k}}\right)$ host. Tolerance could be induced in mice in which $\mathrm{T}$ cells were primed by prior rejection of a donor-strain skin graft, as well as in naive recipients (19).

To evaluate whether this protocol could eventually be used to induce donor-specific tolerance in a clinical setting, it was critical to demonstrate that tolerance induction was generalizable to additional allogeneic MHC class I transgenes and recipient haplotypes. We treated C57BL/6 $\left(\mathrm{H}-2^{\mathrm{b}}\right)$ mice with a hepatocyte-specific AAV 2/8 vector encoding $\mathrm{H}-2 \mathrm{~K}^{\mathrm{d}}\left(\mathrm{AAV}-\mathrm{K}^{\mathrm{d}}\right.$, Supplemental Figure 1; supplemental material available online with this article; https://doi.org/10.1172/jci.insight.97500DS1). Strong expression of H-2K ${ }^{\mathrm{d}}$ was detectable in the livers of transduced mice from day 2 (d2) after inoculation, with near-maximal expression achieved by $\mathrm{d} 7$ (Supplemental Figure 2A). All hepatocytes were transduced at doses between $5 \times 10^{10}$ and $2 \times 10^{12}$ vector genome copies (vgc) (Supplemental Figures 2, B-D). At a dose of $5 \times 10^{11} \mathrm{vgc}$, surface expression of $\mathrm{H}-2 \mathrm{~K}^{\mathrm{d}}$ on transduced hepatocytes was equivalent to that of the native $\mathrm{K}^{\mathrm{d}}$ on hepatocytes of the d-haplotype mouse strain $\mathrm{Dba} / 2$ - and greater than that on hepatocytes of the $\mathrm{H}-2 \mathrm{~K}^{\mathrm{d}}$ transgenic donor strain B6.Kd (Supplemental Figure 2E). Transduced cells showed typical hepatocyte morphology and expressed the hepatocyte marker cytokeratin 8 (Supplemental Figures 2, F and G). Transgene expression was stable and accompanied by minimal cellular infiltration (Supplemental Figures 3, A-F), with serum ALT remaining within the normal range (up to 51 IU/1, ref. 37; Supplemental Figure 3G). While there were no significant changes in overall $\mathrm{CD}^{+}$or $\mathrm{CD} 8^{+} \mathrm{T}$ cell numbers in the liver following inoculation with AAV-K ${ }^{\mathrm{d}}, \mathrm{FoxP}^{+}$cell density increased from $0.7 \pm 0.3$ cells $/$ high-power field (HPF) to $18.3 \pm 4.9$ cells $/ \mathrm{HPF}$ on d14 $(P=0.002$, Supplemental Figure 3, B-D).

To demonstrate tolerance to $\mathrm{H}-2 \mathrm{~K}^{\mathrm{d}}, \mathrm{AAV}-\mathrm{K}^{\mathrm{d}}$-transduced mice received skin grafts from $\mathrm{B} 6 . \mathrm{Kd}$ donors on d7 after inoculation. Dose-dependent survival prolongation was observed, culminating in indefinite survival of all grafts at a dose of $5 \times 10^{11} \mathrm{vgc}$, compared with a median survival time (MST) of 15 days in untreated recipients and 19 days in recipients inoculated with a third-party control vector encoding $\mathrm{H}-2 \mathrm{~K}^{\mathrm{k}}(P=0.0008$; Figure 1A). A modest acceleration of rejection tempo was observed in mice primed by rejection of a B6.Kd graft, compared with unprimed recipients of grafts from the same donor (MST 17 days vs. 22.5 days, $P=0.03$, 
A

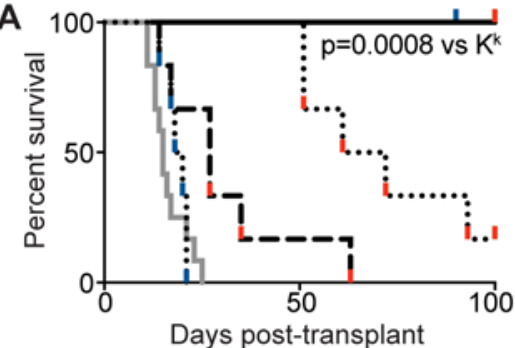

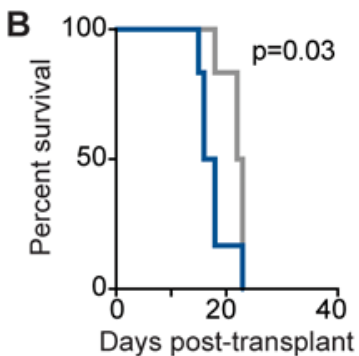

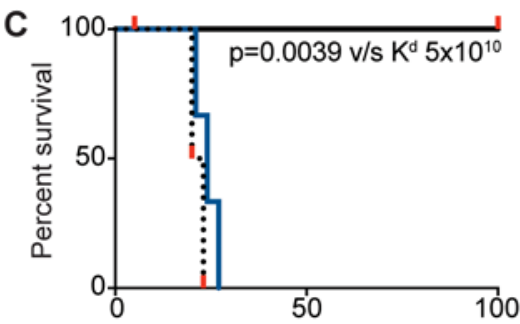

Days post-transplant

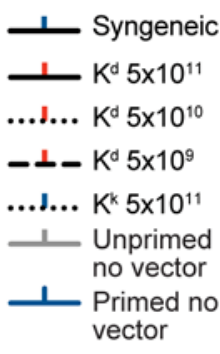

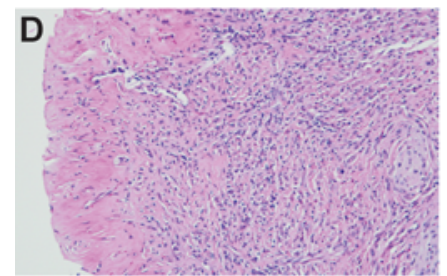
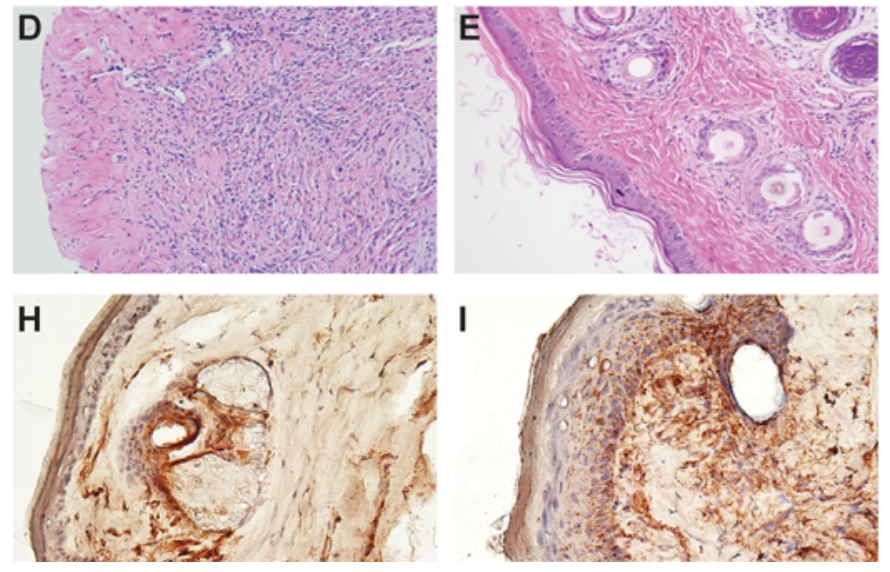
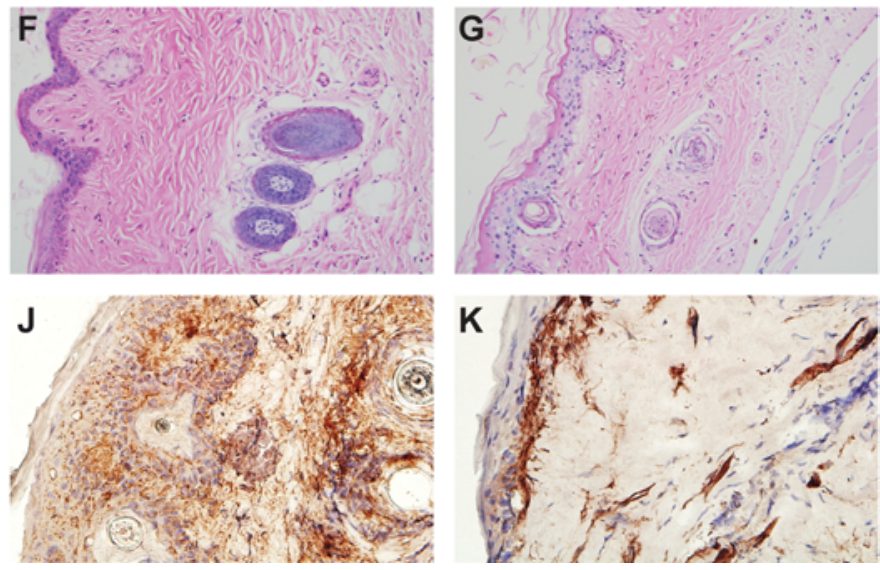

Figure 1. Dose-dependent prolongation of $K^{d}$-bearing skin graft survival after transduction of recipient hepatocytes with AAV-Kd. $(A) C 57 B L / 6$ mice $(n=6 /$ group) were inoculated with AAV-K $K^{d}$ at doses ranging from $5 \times 10^{9}$ to $5 \times 10^{11}$ vector genome copies (vgc) or with $5 \times 10^{11}$ vgc of a control vector encoding the third-party MHC class I molecule H-2Kk. Skin grafts were performed 7 days later. Graft survival was analyzed using the log-rank (Mantel-Cox) test. Syngeneic skin grafts from C57BL/6 donors survived indefinitely. Median survival time (MST) of B6.Kd skin grafts to uninjected C57BL/6 recipients ( $n=12$ ) was 15 days. AAV- $K^{\mathrm{k}}$ did not extend survival (MST 19 days; $P=0.58$ ), whereas a dose-dependent survival prolongation was noted with AAV- $K^{\mathrm{d}}$, culminating in $100 \%$ survival at d100 after transplantation in mice receiving $5 \times 10^{11} \mathrm{vgc} A A V-K^{d}\left(P=0.0008 \mathrm{vs} .5 \times 10^{11} \mathrm{vgc} \mathrm{AAV-K}\right)$. (B) C57BL/6 mice were first primed by receiving a B6.Kd skin graft. Mice were rested for 30-35 days to allow a memory response to develop and then received a secondary graft of B6.Kd skin. A modest acceleration of rejection tempo was observed in primed mice $(n=6)$, compared with unprimed recipients of grafts from the same donor $(n=6 ;$ MST 17 days vs. 22.5 days; $P=$ 0.03; Gehan-Breslow-Wilcoxon test). (C) C57BL/6 mice were primed and rested as above and were then inoculated with AAV-K $\mathrm{K}^{\mathrm{d}}$ at $5 \times 10^{10}(n=3)$ or $5 \times 10^{11}(n=$ 6) vgc i.v., followed after an additional 7 days by a secondary graft. Skin graft survival was analyzed as for $\mathbf{A}$. Median survival of secondary $B 6$.Kd grafts was not prolonged in primed mice treated with $5 \times 10^{10} \mathrm{vgc} A A V-K^{d}$, while all mice inoculated with $5 \times 10^{11} \mathrm{vgc} A A V-K^{d}$ accepted a secondary graft indefinitely $(P=0.0039$

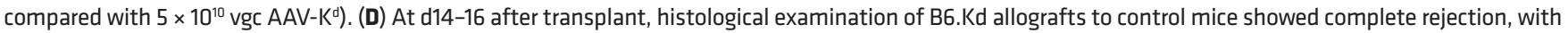
extensive infiltration of the graft and loss of the graft epithelium. (E-G) In contrast, B6.Kd grafts to B10.BR mice inoculated with $5 \times 10^{11} \mathrm{vgc} A A V-K^{d}$ had normal histological appearances at d14-16 (E) and d100 (G), comparable with those of syngeneic grafts (F). (H-J) Expression of $\mathrm{H}-2 \mathrm{~K}^{\mathrm{d}}$ in the tolerated grafts increased early after transplantation (I and $\mathbf{~}$ ) compared with that in freshly collected B6.Kd tail skin (H). (K) Ongoing H-2K ${ }^{\mathrm{d}}$ expression was detectable in tolerated grafts and had returned to baseline levels by d100. Magnification, 200× for D-K.

Figure 1B). Indefinite survival of secondary grafts was obtained in recipients that had been primed 30 days prior to inoculation with $5 \times 10^{11} \mathrm{vgc} A A V-K^{\mathrm{d}}$, whereas graft survival in primed recipients was not prolonged by $5 \times$ $10^{10}$ vgc AAV-K ${ }^{\mathrm{d}}$ (MST 21.5 days compared with 24 days in untreated primed recipients, $P=0.228$, Figure $1 \mathrm{C}$ ). A heavy cellular infiltrate was present in rejecting grafts, accompanied by complete loss of the graft epithelium (Figure 1D). In contrast, the histological appearances of long-surviving B6.Kd allografts to mice transduced with AAV-K ${ }^{\mathrm{d}}$ resembled those of syngeneic transplants (Figure 1, E-G), and persistent expression of the allogeneic MHC class I was detectable (Figure $1, \mathrm{H}-\mathrm{K}$ ). These findings in the $\mathrm{H}-2 \mathrm{~K}^{\mathrm{d}}$ to $\mathrm{H}-2^{\mathrm{b}}$ model closely parallel the original observations in $\mathrm{H}-2^{\mathrm{k}}$ mice transduced with $\mathrm{AAV}-\mathrm{K}^{\mathrm{b}}$, suggesting that expression of allogeneic MHC class I in recipient hepatocytes is a broadly applicable strategy for transplant tolerance induction.

The D227K mutation does not affect membrane expression of allogeneic MHC class I molecules. To determine the contribution of intact vs. processed donor class I in tolerance induction, we generated AAV-K ${ }^{\mathrm{b}}-\mathrm{D} 227 \mathrm{~K}$ and $\mathrm{K}^{\mathrm{d}}$-D227K vectors (Supplemental Figure 1, B and C) in which a point mutation in the $\alpha 3$ domain of the encoded class I heavy chains abrogates CD8 binding to MHC class I (33-36), thus impeding direct allorecognition. WT and mutant (D227K) MHC class I molecules were expressed at comparable levels on the surface of transduced hepatocytes on $\mathrm{d} 7$ following a dose of $5 \times 10^{11} \mathrm{vgc}$ of the relevant vectors (Figure 2).

The D227K mutation disrupts recognition of intact allogeneic MHC class I, without affecting recognition of processed class $I$. To test the effects of the $\mathrm{D} 227 \mathrm{~K}$ mutation on the direct and indirect allorecognition pathways, 
A

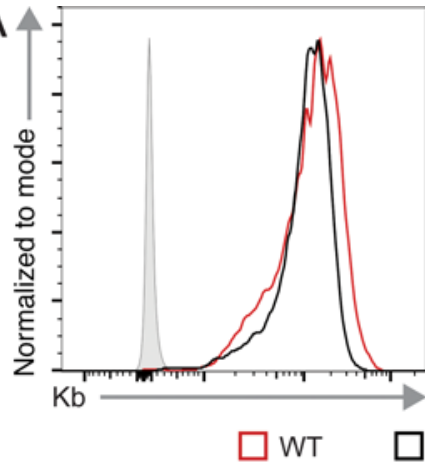

B

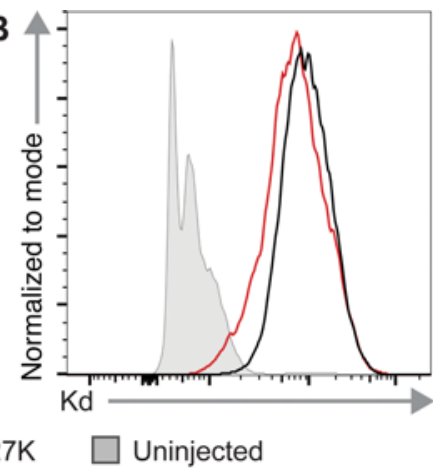

Figure 2. Comparable expression of D227K-mutant and WT MHC class I molecules in recipient hepatocytes. Flow cytometry was used to determine expression of MHC class I transgenes in recipient liver at d7 after inoculation with AAV- $\mathrm{K}^{\mathrm{b}}, \mathrm{K}^{\mathrm{b}}-\mathrm{D} 227 \mathrm{~K}, \mathrm{~K}^{\mathrm{d}}$, and $\mathrm{K}^{\mathrm{d}}-\mathrm{D} 227 \mathrm{~K}$ vectors. The epitopes recognized by the monoclonal antibodies $\mathrm{B} 8-24.2\left(\mathrm{~K}^{\mathrm{b}}\right)$ or $15-5-$ $5 \mathrm{~S}\left(\mathrm{~K}^{\mathrm{d}}\right)$ do not include the $\alpha 3$ domain containing the D227K mutation. Comparable expression of $\mathrm{K}^{\mathrm{b}}$ was detected in B10. $B R$ hepatocytes isolated from mice transduced with either AAV- $K^{b}$ or AAV- $K^{b}-D 227 K(A)$. Similarly, equivalent levels of $K^{d}$ expression were detected on hepatocytes from $\left[57 \mathrm{BL} / 6\right.$ mice inoculated with $A A V-K^{d}$ or $K^{d}-D 227 K(B)$. Experiments were performed twice with 2 replicate mice per group on each occasion. Representative histograms are shown.

TCR-transgenic T cells recognizing intact (Des-TCR RAG1 ${ }^{-/}$[Des-RAG]) or processed (TCR75-RAG1 ${ }^{-/}$ [TCR75-RAG]) allogeneic class I were used as reporter cells in adoptive transfer experiments. Alloreactive Des-RAG $\mathrm{CD} 8^{+} \mathrm{T}$ cells $\left(\mathrm{H}-2^{\mathrm{k}}\right.$ haplotype) directly recognize $\mathrm{H}-2 \mathrm{~K}^{\mathrm{b}}$ complexed with 1 of 3 ubiquitously expressed self-peptides (38). CFSE-labeled Des-RAG T cells were transferred to syngeneic B10.BR recipient mice transduced with either $\mathrm{AAV}-\mathrm{K}^{\mathrm{b}}$ or $\mathrm{AAV}-\mathrm{K}^{\mathrm{b}}-\mathrm{D} 227 \mathrm{~K}$ at $\mathrm{d} 2$ after inoculation with $\mathrm{rAAV}$, and liver leucocytes were isolated from these mice following a further 2 days (Figure 3A). Des-RAG cells recovered from mice expressing WT H-2 $\mathrm{K}^{\mathrm{b}}$ on hepatocytes expressed the activation markers CD69 (Figure 3B) and PD-1 (Figure 3C) and started to divide. In contrast, Des-RAG T cells isolated from the livers of mice expressing $\mathrm{H}-2 \mathrm{~K}^{\mathrm{b}}$-D227K did not show any evidence of activation or proliferation (Figures 3, B and C). Consistent with the observed difference in the extent of proliferation between Des-RAG cells transferred to mice inoculated with $\mathrm{AAV}-\mathrm{K}^{\mathrm{b}}$ or $\mathrm{K}^{\mathrm{b}}-\mathrm{D} 227 \mathrm{~K}$ vectors, the absolute number of cells recovered from the $\mathrm{K}^{\mathrm{b}}$-expressing livers was $56,421 \pm 13,959$, compared with 2,482 \pm 861 cells recovered from livers expressing $\mathrm{K}^{\mathrm{b}}$-D227K (Figure 3D, $P=0.02$ ), corresponding to a 20 -fold difference in the proportion of Des-RAG T cells within the liver leucocyte populations $(P=0.04$, Figure $3 \mathrm{E})$.

CD4 ${ }^{+}$TCR75-RAG T cells (H-2 ${ }^{b}$ haplotype) recognize a $\mathrm{K}^{\mathrm{d}}$-derived peptide (QEGPEYWEEQTQRAK) complexed with IA ${ }^{b}$. CFSE-labeled TCR75-RAG cells were adoptively transferred to C57BL/6 recipients 7 days following injection with either $\mathrm{AAV}-\mathrm{K}^{\mathrm{d}}$ or $\mathrm{AAV}-\mathrm{K}^{\mathrm{d}}-\mathrm{D} 227 \mathrm{~K}$, and they were recovered from the liver, spleen, or draining lymph node (LN) 3 days later (Figure 4A). B6.Kd mice, which constitutively express the peptide on all antigen-presenting cells, were used as a positive control. In all 3 compartments, proliferation of the transferred TCR75-RAG cells was comparable in mice transduced with either vector (Figure 4B, Supplemental Figure 4). In the liver and draining LN, proliferation in the AAV-transduced mice was almost as extensive as that occurring in B6.Kd mice, while in the spleen, TCR75-RAG cells had undergone fewer divisions in the AAV-transduced mice than in the B6.Kd controls (Figure 4B). Expression of the activation markers CD69 and PD-1 followed similar patterns in mice transduced with AAV-K ${ }^{\mathrm{d}}$ or AAV-K $\mathrm{K}^{\mathrm{d}} \mathrm{D} 227 \mathrm{~K}$; surface expression of CD69 slowly declined with succeeding cell divisions (Figure 4C), while that of PD-1 increased (Figure 4D). Taken together, these reporter cell experiments confirm that the D227K mutation abrogates recognition of intact allogeneic MHC class I by CD8-dependent $\mathrm{T}$ cells, while recognition of processed class I peptides by $\mathrm{CD} 4^{+} \mathrm{T}$ cells is unimpaired.

There was a significant increase in the proportion of activated $\mathrm{CD} 8^{+} \mathrm{T}$ cells $\left(\mathrm{CD} 44^{+} \mathrm{PD}-1^{+}\right)$among the liver leucocytes of mice transduced with AAV- $\mathrm{K}^{\mathrm{d}}$ (peaking at $36.8 \% \pm 2.0 \%$ on d10 compared with $1.2 \%$ $\pm 0.3 \%$ on $\mathrm{d} 2, P<0.0001$ ) (Figure $5, \mathrm{~A}$ and $\mathrm{B}$ ), consistent with an endogenous alloresponse with potential contributions from both direct and indirect recognition of $\mathrm{H}-2 \mathrm{~K}^{\mathrm{d}}$. A more modest increase in the proportion of $\mathrm{CD} 44^{+} \mathrm{PD}-1^{+} \mathrm{CD} 8{ }^{+} \mathrm{T}$ cells in C57BL/ 6 mice transduced with AAV-K ${ }^{\mathrm{d}}-\mathrm{D} 227 \mathrm{~K}$ was detected $(9.5 \%$ $\pm 3.8 \%$ on $\mathrm{d} 10$, against $0.95 \% \pm 0.52 \%$ on $\mathrm{d} 2, P=0.014)$, suggesting that some recognition of processed 
A
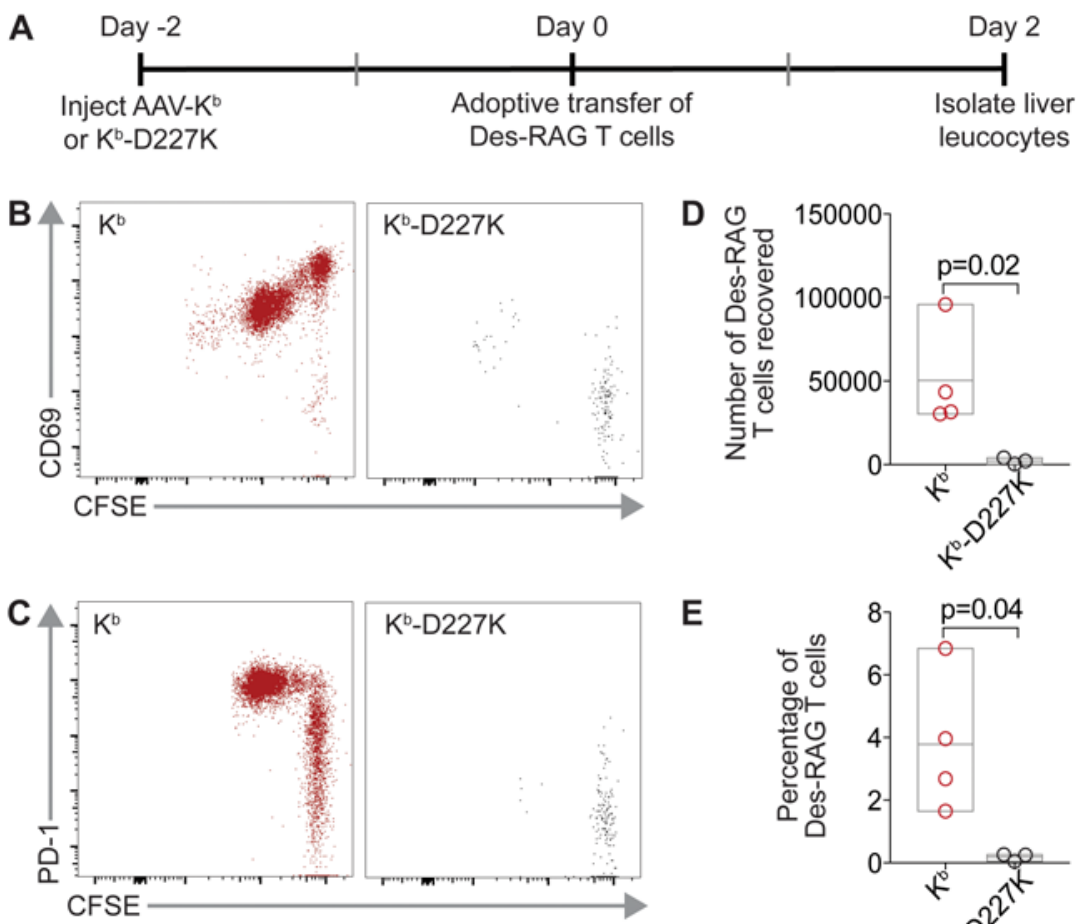

E

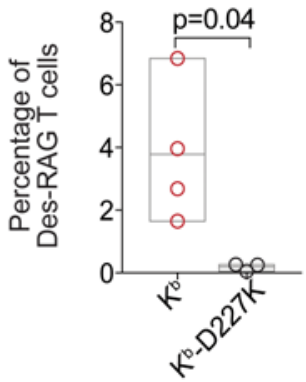

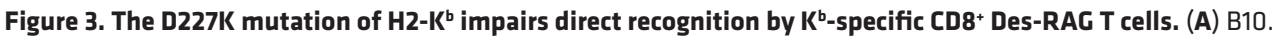
$\mathrm{BR}$ mice were inoculated with $5 \times 10^{11} \mathrm{vgc} A A V-K^{b}$ or $\mathrm{K}^{\mathrm{b}}$-D227K. Two days later, $1 \times 10^{6} \mathrm{CFSE}$-labeled Des-RAG lymph node cells were adoptively transferred to these recipient mice. After a further 48 hours, liver leucocytes were isolated, stained, and examined by flow cytometry. (B and $\mathbf{C}$ ) Des-RAG cells transferred into mice transduced with AAV-K ${ }^{\mathrm{b}}$ expressed the activation markers CD69 (B) and PD-1 (C) and had started to divide. In contrast, Des-RAG cells recovered from the livers of mice inoculated with AAV-Kb-D227K showed no signs of activation or proliferation. (D) Consistent with the observed difference in the extent of proliferation between Des-RAG cells transferred to mice inoculated with AAV- $K^{b}$ or $K^{b}$-D227K vectors, the absolute number of Des-RAG cells recovered from the Kb-expressing livers was 56,421 $\pm 13,959$, compared with $2,482 \pm 861$ cells recovered from livers expressing $K^{b}-D 227 K ; P=0.02$. (E) Des-RAG T cells comprised $3.78 \% \pm 1.12 \%$ of leucocytes recovered from the livers of mice transduced with AAV- $K^{\mathrm{b}}$ and $0.19 \%$ of liver leucocytes in AAV-K $K^{\mathrm{b}}-\mathrm{D} 227 \mathrm{~K}$-treated mice $(P=0.04)$. This experiment was performed twice with $3-4$ mice/group for each experiment. Representative dot plots are shown. Box shows minimum to maximum, with a line at the mean. Data are described as mean \pm SEM and were analyzed using an unpaired $t$ test.

$\mathrm{K}^{\mathrm{d}}$ peptides by $\mathrm{CD} 8^{+} \mathrm{T}$ cells does occur in C57BL/6 recipients following $\mathrm{K}^{\mathrm{d}}$ expression. From d4-10, the proportion of activated $\mathrm{CD} 8^{+} \mathrm{T}$ cells was significantly greater in the livers of mice transduced with $\mathrm{AAV}-\mathrm{K}^{d}$ than those treated with AAV-K ${ }^{\mathrm{d}}-\mathrm{D} 227 \mathrm{~K}(P<0.0001$, Figure 5B). A similar pattern was noted in splenocytes from inoculated mice, although the proportions of activated $\mathrm{CD} 8^{+} \mathrm{T}$ cells in the spleen were much smaller than those in liver (Figure 5C). Absolute numbers of activated CD8 ${ }^{+} \mathrm{T}$ cells in these tissues were consistent with the observed proportions (Supplemental Figure 5).

Tolerance to subsequent skin allografts depends upon recognition of intact allogeneic $M H C$ class $I$. $\mathrm{H}-2 \mathrm{~K}^{\mathrm{b}}$ bearing skin from 178.3 mice was grafted onto B10.BR recipients transduced with either AAV-K $\mathrm{K}^{\mathrm{b}}$ or AAV-K $\mathrm{K}^{\mathrm{b}} \mathrm{D} 227 \mathrm{~K}$ at a dose of $5 \times 10^{11} \mathrm{vgc}, 7$ days prior to transplantation. Uninjected B10.BR mice rejected $\mathrm{H}-2 \mathrm{~K}^{\mathrm{b}}$-mismatched 178.3 skin with a MST of 16 days, while grafts on to AAV-K ${ }^{\mathrm{b}}$-injected mice survived indefinitely $(P<0.0001)$. Administration of AAV-K $\mathrm{K}^{\mathrm{b}}-\mathrm{D} 227 \mathrm{~K}$ slightly prolonged graft survival (MST 27 days; $P=0.0016$, compared with uninjected mice) but tolerance was not achieved $\left(P=0.0005\right.$, compared with mice transduced with AAV- $\mathrm{K}^{\mathrm{b}}$; Figure $\left.6 \mathrm{~A}\right)$. These results were recapitulated in the B6.Kd to $\mathrm{C} 57 \mathrm{BL} / 6$ model. Skin grafts mismatched for $\mathrm{H}-2 \mathrm{~K}^{\mathrm{d}}$ were transplanted from B6.Kd donors to C57BL/ 6 recipients 7 days following inoculation with $5 \times 10^{11} \mathrm{vgc} \mathrm{AAV-K}$ or AAV$\mathrm{K}^{\mathrm{d}}-\mathrm{D} 227 \mathrm{~K}$. Grafts to mice transduced with AAV-K $\mathrm{K}^{\mathrm{d}}$ survived indefinitely, while MST was 15 days in untreated C57BL/ 6 recipients $(P=0.0001)$. A modest survival prolongation of B6.Kd skin grafts was achieved when recipient mice were transduced with AAV-K ${ }^{\mathrm{d}}$-D227K (MST 28.5 days; $P=0.0002$, 
A

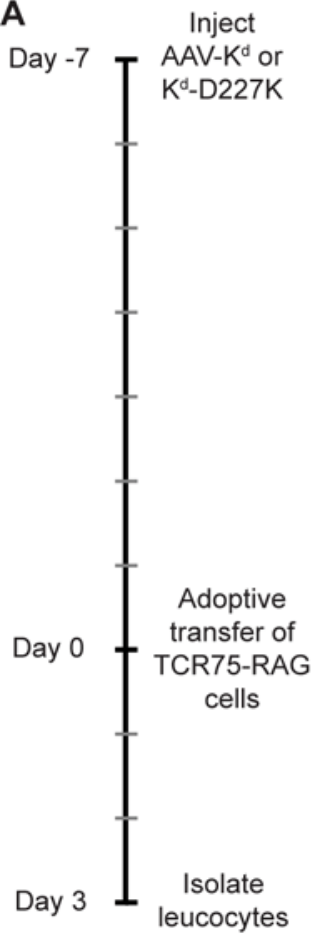

B

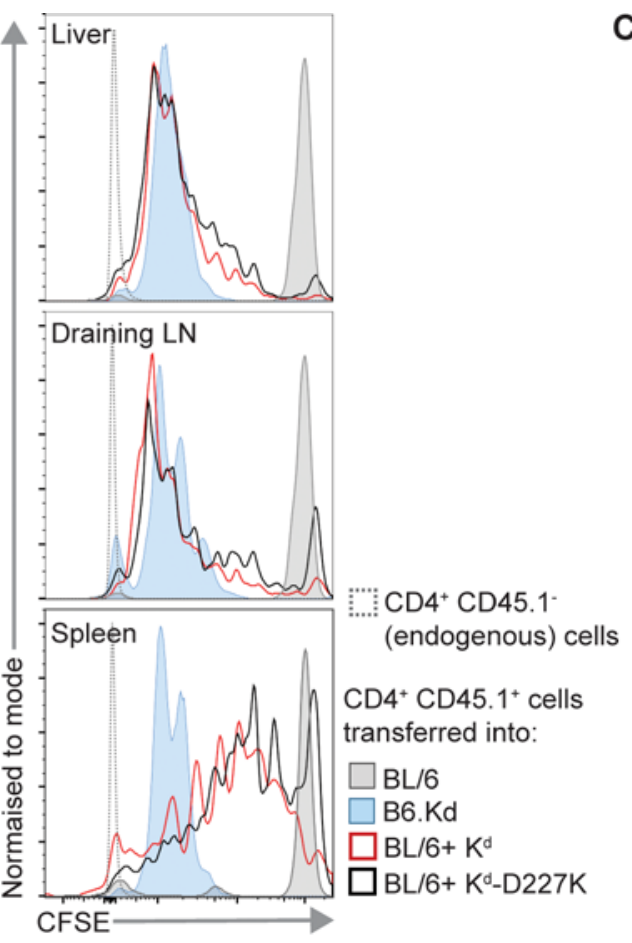

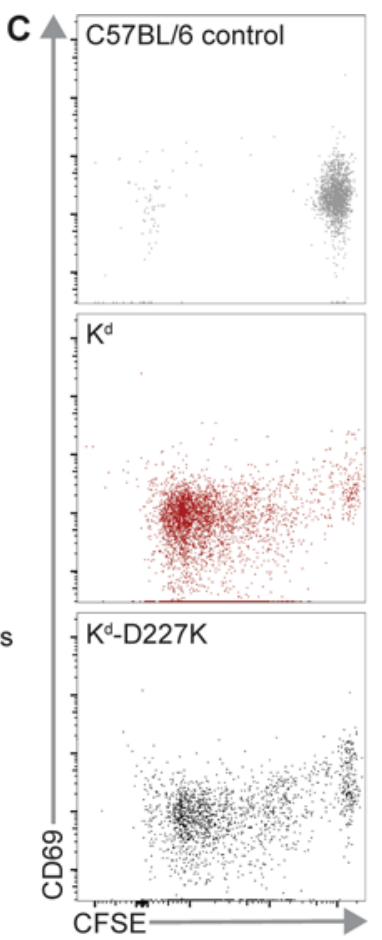

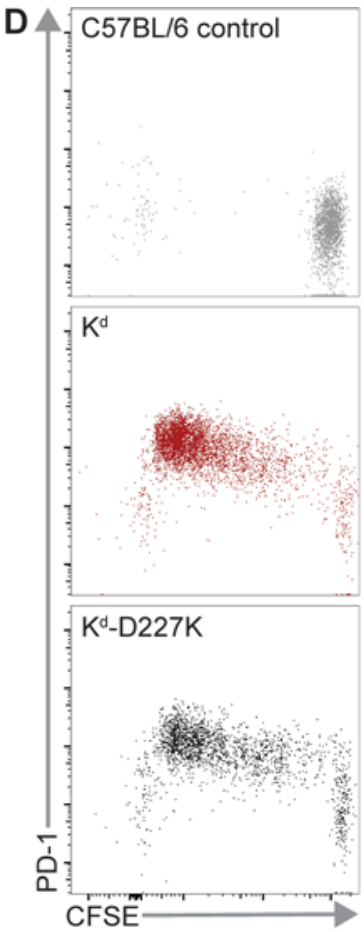

Figure 4. The D227K mutation does not impede indirect recognition of $K^{d}$ by indirectly alloreactive TCR75-RAG T cells. (A) C57BL/6 mice were inoculated with $5 \times 10^{11} \mathrm{vgc} A A V-K^{d}$ or $K^{d}-D 227 K$. B6.Kd mice, which constitutively express the $\mathrm{I}^{\mathrm{b}}-\mathrm{K}^{\mathrm{d}(54-68)}$ epitope on antigen-presenting cells, were positive-control recipients, while C57BL/ 6 mice were used as negative controls. CFSE-labeled TCR75-RAG lymphocytes $\left(1 \times 10^{7}\right)$ were transferred to vector-transduced and control mice 7 days after inoculation. After a further 3 days, leucocytes were isolated from the spleen, liver, and liver-draining LN; stained; and examined by flow cytometry ( $n=3-4$ / group). (B) The congenic marker CD45.1 was used, along with CD4, to identify transferred TCR75-RAG cells. TCR75-RAG cells proliferated to a similar extent when transferred to mice transduced with either AAV-K (red line) or AAV-K ${ }^{\mathrm{d}}-\mathrm{D} 227 \mathrm{~K}$ (black line). TCR75-RAG cells transferred into C57BL/6 recipients did not divide (gray filled histogram). In the liver and draining LN, the extent of proliferation was similar to that in positive control B6.Kd mice, while in the spleen, proliferation had progressed further in the positive control than in the transduced mice. Representative histograms are shown ( $n=3-4 /$ group). (C and $\mathbf{D})$ In mice inoculated with either AAV- $K^{\mathrm{d}}$ or $\mathrm{K}^{\mathrm{d}}-\mathrm{D} 227 \mathrm{~K}$, similar patterns of expression of CD69 and PD-1 on TCR75-RAG cells were observed. CD69 surface expression declined with successive cell divisions (C), while PD-1 expression levels increased as division progressed (D). Representative plots from the draining LN ( $n=3 /$ group) are shown.

compared with uninjected recipients), but again, tolerance was not induced ( $P=0.0005$, compared with recipients inoculated with AAV-K ${ }^{\mathrm{d}}$; Figure 6B).

IFN- $\gamma$ production by alloreactive responder cells is reduced by recognition of intact but not processed MHC class I. Recipient anti-donor alloresponses were measured using IFN- $\gamma$ ELISpot. C57BL/6 mice were primed against $\mathrm{H}-2 \mathrm{~K}^{\mathrm{d}}$ using a $\mathrm{B} 6 . \mathrm{Kd}$ skin graft, and were then rested for 30-35 days after rejection to allow development of a memory response. The number of responder cells producing IFN- $\gamma$ upon exposure to $\mathrm{H}-2 \mathrm{~K}^{\mathrm{d}}$-bearing stimulators increased from $41.78 \pm 16.45$ spot-forming cells $(\mathrm{SFC}) /$ million unfractionated splenocytes $\left(\mathrm{SFC} / 1 \times 10^{6}\right)$ in naive $\mathrm{C} 57 \mathrm{BL} / 6$ to $336.1 \pm 71.67 \mathrm{SFC} / 1 \times 10^{6}$ in primed mice $(P=$ 0.0009 , Figure 7A). Inoculation of primed C57BL/6 mice with AAV-K $\mathrm{K}^{\mathrm{d}}$ significantly decreased IFN- $\gamma$ production $\left(117.4 \pm 22.36 \mathrm{SFC} / 1 \times 10^{6} ; P=0.0217\right.$, compared with primed uninjected mice; Figure $7 \mathrm{~A})$, while treatment with AAV- $\mathrm{K}^{\mathrm{d}}-\mathrm{D} 227 \mathrm{~K}$ did not reduce the anti-H-2K ${ }^{\mathrm{d}}$ response $(247.4 \pm 66.33$ $\mathrm{SFC} / 1 \times 10^{6}, P=0.4730$ ). Parallel results were obtained when pooled, CD8-enriched splenocytes from primed mice were used as responders (Figure 7B).

Depletion of $C D 4^{+}$Tregs abrogates skin graft survival prolongation following gene transfer of CD8 interaction mutant but not WT allogeneic MHC class $I$. The modest survival prolongation that was observed when recipients were treated with rAAV-K $\mathrm{K}^{\mathrm{b}}-\mathrm{D} 227 \mathrm{~K}$ or $\mathrm{rAAV}-\mathrm{K}^{\mathrm{d}}-\mathrm{D} 227 \mathrm{~K}$ may be due to recognition of processed donor MHC class I by recipient $\mathrm{CD} 4^{+}$or $\mathrm{CD} 8^{+} \mathrm{T}$ cells. To ascertain whether the generation or activation of $\mathrm{CD}^{+}$Tregs in response to $\mathrm{H}-2 \mathrm{~K}^{\mathrm{b}}$ or $\mathrm{H}-2 \mathrm{~K}^{\mathrm{d}}$ allopeptides was contributing to this survival prolongation, Tregs were depleted from some recipients, employing anti-folate receptor 4 (anti-FR4) antibodies in WT mice (Figures 8 and 9) or Diphtheria toxin (DT) in depletion of regulatory T cell (DEREG) mice (Figure 10). To reduce Treg numbers, AAV-transduced B10.BR recipients received the anti-FR4 antibody 
A
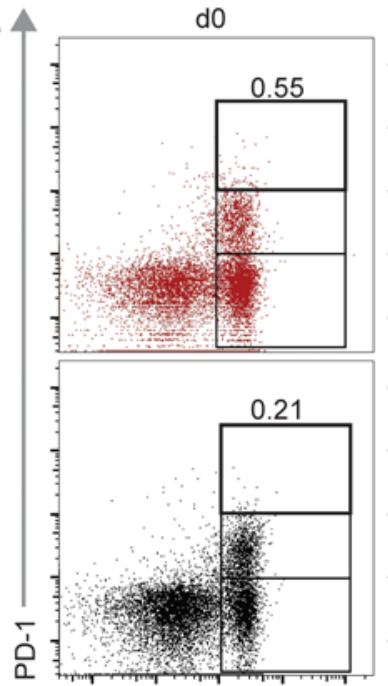
CD44

B

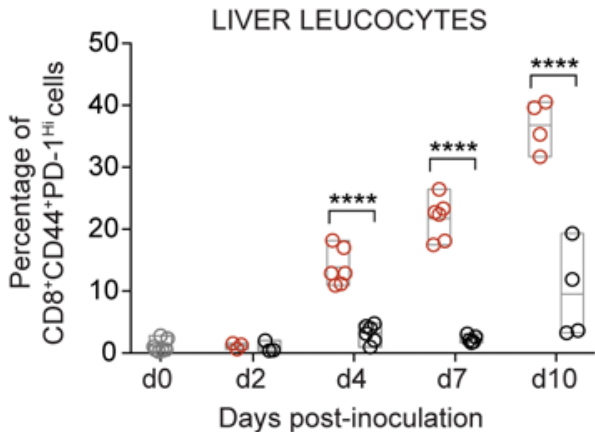

Days post-inoculation d2
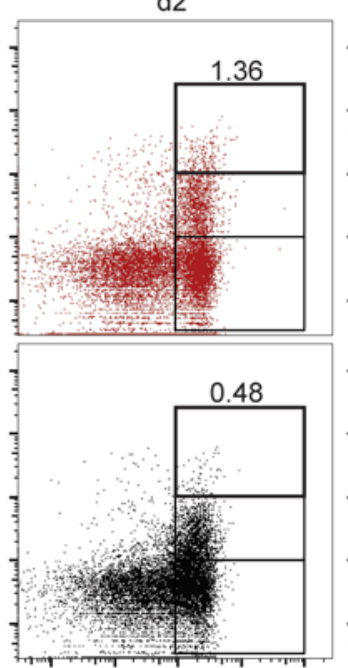

d4
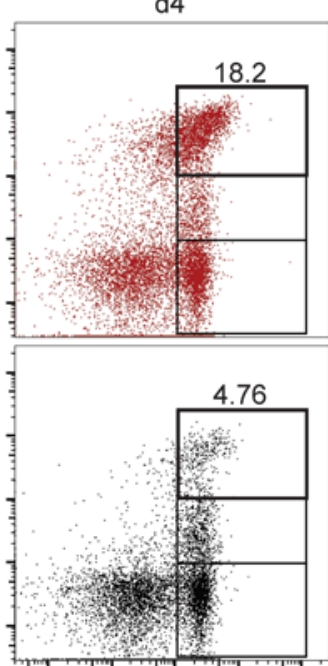

d7
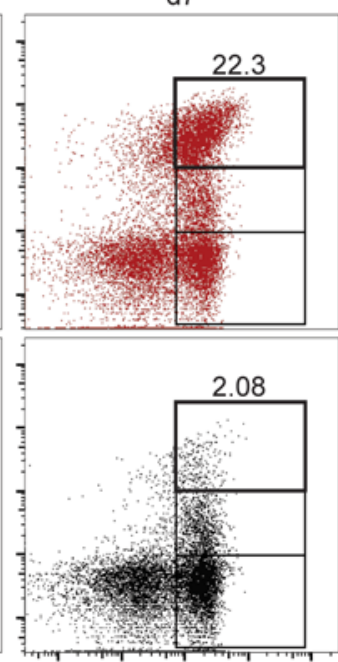
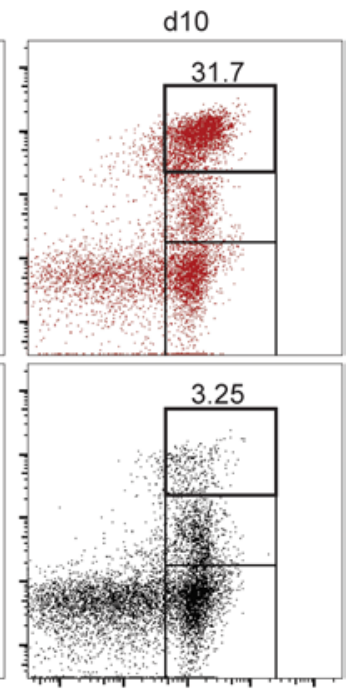

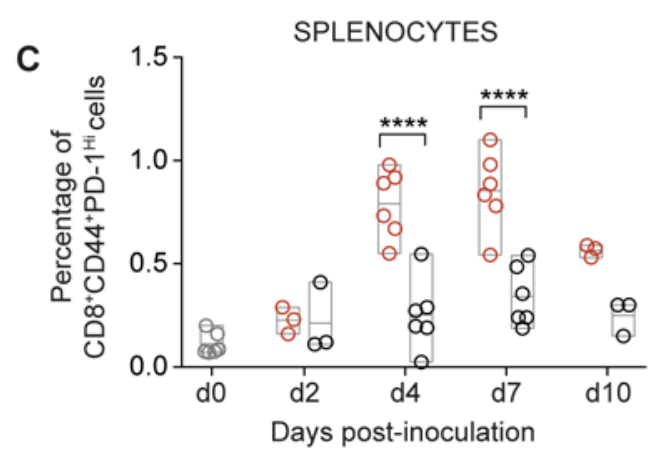

[0] C57BL6

[.] $\mathrm{C} 57 \mathrm{BL} / 6+\mathrm{K}^{\mathrm{d}}$

(2) C57BL/6 + Kd $-\mathrm{D} 227 \mathrm{~K}$

$\star * * * p<0.0001$

Figure 5. Activation of endogenous CD8 ${ }^{+}$alloreactive T cells in the presence or absence of direct recognition of allogeneic MHC class I. C57BL/6 mice were transduced with $5 \times 10^{11} \mathrm{vgc} A A V-K^{\mathrm{d}}$ or $\mathrm{K}^{\mathrm{d}}-\mathrm{D} 227 \mathrm{~K}$. At intervals between 48 hours and 10 days after inoculation, leucocytes were isolated from liver, draining LN, and spleen, and CD3+CD8+ T cells were analyzed for expression of the activation markers CD44 and PD-1. (A) The frequency of PD-1hi cells among $C D 8^{+} T$ cells from liver increased substantially during the first 10 days after inoculation in mice treated with AAV-K $K^{d}$ and, to a lesser extent, in mice transduced with $\mathrm{K}^{\mathrm{d}}$-D227K. $n=3-6$ mice/group; representative plots shown. (B) Data were analyzed using a 2-way ANOVA with Sidak's and Tukey's post tests; the proportion of activated (CD44+PD- $1^{\text {hi }}$ ) CD8 ${ }^{+} T$ cells in liver peaked at $36.8 \% \pm 2.0 \%$ on d10 after inoculation with AAV- $K^{\mathrm{d}}$ compared with $1.2 \% \pm 0.3 \%$ on d2 $(P<0.0001)$. In mice that had received AAV-K $K^{\mathrm{d}}-\mathrm{D} 227 \mathrm{~K}$, the proportion of CD44 ${ }^{+} \mathrm{PD}-1^{\mathrm{Hi}} \mathrm{CD} 8^{+} \mathrm{T}$ cells was $9.5 \% \pm 3.8 \%$ on $\mathrm{d} 10$, compared with $0.95 \% \pm 0.52 \%$ on $\mathrm{d} 2\left(P=0.014, n=3-6\right.$ /group). From d4-10, the proportion of activated CD8 ${ }^{+} \mathrm{T}$ cells was significantly greater in the livers of mice transduced with AAV- $K^{\mathrm{d}}$ than those treated with AAV- $K^{\mathrm{d}}-\mathrm{D} 227 \mathrm{~K}(P<0.0001)$. (C) Parallel changes were noted in splenocytes and $\mathrm{LN}$ cells $($ not shown) from inoculated mice ( $n=3-6 /$ group), although the proportions of activated CD8 ${ }^{+}$T cells in spleen or LN were much smaller than those in liver, and the peak proportions of activated CD8 ${ }^{+}$T cells were attained on $\mathrm{d} 7\left(0.85 \% \pm 0.08 \%\right.$ for $A A V-K^{\mathrm{d}}$-transduced mice, $0.34 \% \pm 0.7 \%$ for mice receiving AAV-K $-\mathrm{D} 227 \mathrm{~K}$, and $0.11 \% \pm 0.02 \%$ in untransduced mice). Statistical analysis employed 2-way ANOVA with Sidak's and Tukey's post tests. Box shows minimum to maximum with a line at the mean. Data are described as mean \pm SEM.

TH6. The nondepleting anti-FR4 antibody 12A5 does not compete for epitope binding against TH6 (Supplemental Figure 6A) and was used for FR4 detection. TH6 treatment significantly reduced the numbers of $\mathrm{CD}^{+}{ }^{+} \mathrm{FoxP}^{+} \mathrm{T}$ cells in both peripheral blood $\left(6.98 \times 10^{4} \pm 9.72 \times 10^{3}\right.$ vs. $1.09 \times 10^{4} \pm 5.38$ $\times 10^{3}, P=0.008$, Figure $8, \mathrm{~A}$ and $\left.\mathrm{C}\right)$ and spleen $\left(1.03 \times 10^{6} \pm 2.19 \times 10^{4}\right.$ vs. $7.86 \times 10^{5} \pm 5.17 \times 10^{4}, P=$ 0.01 , Figure $8, \mathrm{~B}$ and D) while having no effect upon CD $8^{+} \mathrm{T}$ cells (Supplemental Figure $6, \mathrm{~B}$ and $\mathrm{C}$ ). A substantial proportion of $\mathrm{CD} 4^{+} \mathrm{FoxP}^{+} \mathrm{T}$ cells express both $\mathrm{CD} 25$ and FR4. As expected, the number of these cells in peripheral blood and spleen declined significantly following TH6 administration (Figure 8, $\mathrm{C}$ and $\mathrm{D}$ ). While the reduction of the $\mathrm{FR} 4^{+}$fraction in spleen was accompanied by an overall decrease in $\mathrm{CD}^{+}{ }^{+} \mathrm{FoxP}^{+} \mathrm{T}$ cell numbers, there was also an increase in the proportion of $\mathrm{CD} 25^{+} \mathrm{FR} 4^{-}$cells upon $\mathrm{TH} 6$ treatment (Figure 8B), suggesting that FR4 engagement may have resulted in shedding or internalization of this receptor on some cells, as previously observed (39). The survival prolongation of 178.3 skin grafts in B10.BR mice inoculated with $\mathrm{K}^{\mathrm{b}}-\mathrm{D} 227 \mathrm{~K}$ was abrogated when the recipients were treated with anti-FR4 (clone TH6). MST was reduced from 27 days in AAV-K $\mathrm{K}^{\mathrm{b}}-\mathrm{D} 227 \mathrm{~K}$-transduced mice receiving an isotype-control antibody to 17.5 days in mice receiving anti-FR4 $(P=0.042$, Figure 9B). Skin graft 

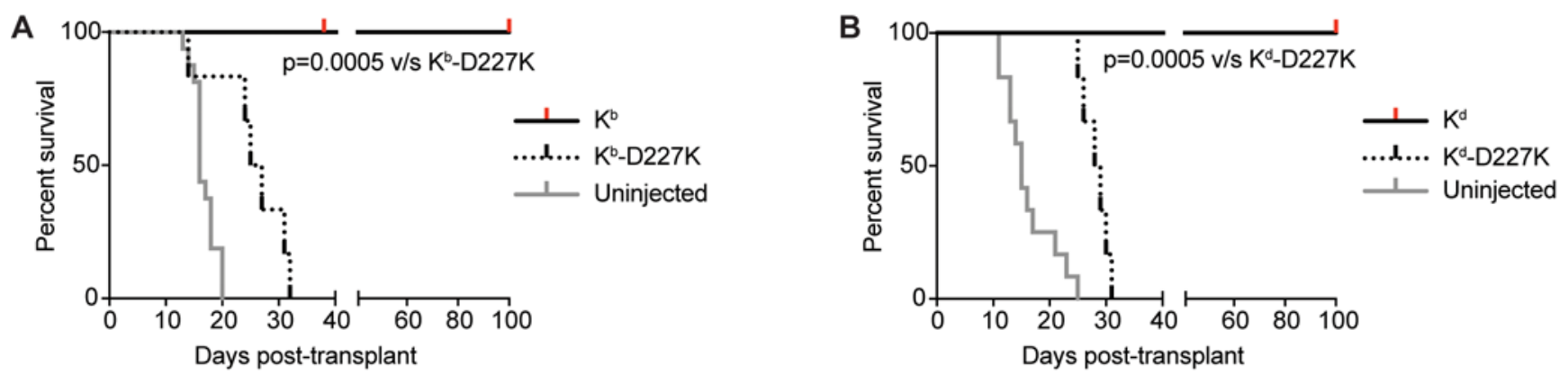

Figure 6. Allogeneic skin graft tolerance induction requires recognition of intact donor MHC class I. (A) B10.BR mice were injected with $5 \times 10^{11} \mathrm{vgc}$ AAV- $\mathrm{K}^{\mathrm{b}}(n=6)$ or $\mathrm{K}^{\mathrm{b}}$-D227K $(n=6)$, or were not transduced $(n=16)$. Seven days later, mice received 178.3 skin grafts, which express $\mathrm{K}^{\mathrm{b}}$ on an $\mathrm{H}-2^{\mathrm{k}}$ background. Statistical analysis of graft survival was carried out using the log-rank (Mantel-Cox) test. Modest graft survival prolongation was observed in mice transduced with AAV-K ${ }^{\mathrm{b}}$-D227K (MST 26 days vs. 16 days in uninjected controls, $\left.P=0.0016\right)$, but tolerance was not achieved. Conversely, all mice inoculated with AAV- $K^{\mathrm{b}}$ accepted 178.3 skin grafts indefinitely $\left(P=0.0005 \mathrm{vs}\right.$. $\left.\mathrm{K}^{\mathrm{b}}-\mathrm{D} 227 \mathrm{~K}\right)$. (B) C57BL/6 mice received $5 \times 10^{11} \mathrm{vgc} A A V-K^{\mathrm{d}}$ or $\mathrm{K}^{\mathrm{d}}-\mathrm{D} 227 \mathrm{~K}(n$ $=6$ per group) or no vector $(n=12)$ and, after a further 7 days, were transplanted with B6.Kd skin ( $K^{\mathrm{d}}$-transgenic on an $\mathrm{H}-2^{\mathrm{b}}$ background). Survivals were analyzed as for $\mathbf{A}$. Skin graft survival was increased to 28.5 days in mice transduced with AAV-Kd-D227K compared with 15 days in untransduced recipients $(P=0.001)$, but again, tolerance was not induced. All grafts survived beyond 100 days in mice transduced with AAV- $K^{\mathrm{d}}\left(P=0.0005\right.$ vs. $\left.K^{\mathrm{d}}-\mathrm{D} 227 \mathrm{~K}\right)$.

survival in the D227K-FR4 group was equivalent to that in uninjected recipients (MST 17.5 days vs.. $16 \mathrm{~d}, P=0.469)$, while neither anti-FR4 nor control antibody administration influenced the survival of syngeneic skin grafts or of $\mathrm{H}-2 \mathrm{~K}^{\mathrm{b}}$-mismatched grafts to B10.BR mice transduced with $\mathrm{AAV}-\mathrm{K}^{\mathrm{b}}(\mathrm{MST}>$ 100 days for all groups).

The proportion of $\mathrm{CD}^{+} \mathrm{T}$ cells expressing FoxP3 fell from $14.4 \% \pm 1.7 \%$ to $0.965 \pm 0.19 \%$ in the peripheral blood of DEREG mice treated with DT $\left(P=0.0015\right.$; Figure 10, A and C). Similarly, CD4 ${ }^{+}$ FoxP $^{+} \mathrm{T}$ cells were reduced from $23.1 \% \pm 1.8 \%$ to $5.7 \% \pm 0.8 \%$ in DT-treated DEREG spleen (Figure 10, $\mathrm{B}$ and $\mathrm{C})$. Absolute numbers of $\mathrm{CD}^{+} \mathrm{FoxP}^{+} \mathrm{T}$ cells declined from 42,067 $\pm 3,982$ to $971 \pm 192$ in the peripheral blood of DT-treated DEREG mice $(P=0.0005)$ and from $1.5 \times 10^{6} \pm 0.5 \times 10^{6}$ to 1.08 $\times 10^{5} \pm 0.63 \times 10^{5}$ in spleen $(P=0.038$, Figure $10 \mathrm{D})$. The number and proportion of FoxP3 $3^{+}$cells in C57BL/6 mice were unaffected by DT administration (Supplemental Figures 7B and Supplemental Figure 8B). The effect of DT administration on other cell subsets is shown in Supplemental Figures 7 and 8 . The survival prolongation of $\mathrm{K}^{\mathrm{d}}$-mismatched B6.Kd grafts onto DEREG recipients treated with rAAV-K ${ }^{\mathrm{d}}$-D227K (MST 27 days) was blocked when mice receiving $\mathrm{K}^{\mathrm{d}}$-D227K were also treated with DT (MST 18 days; $P=0.0046$; Figure 10F). Treg depletion did not shorten the survival of skin grafts in mice inoculated with AAV encoding WT H-2K $\mathrm{K}^{\mathrm{d}}$ (MST $>100$ days) or in mice with no viral vector treatment ( $20 \mathrm{~d}$ vs. $18 \mathrm{~d}, P=0.51$ ). To determine whether Tregs generated in response to either direct presentation of $\mathrm{H}-2 \mathrm{~K}^{\mathrm{d}}$ or indirect presentation of $\mathrm{H}-2 \mathrm{~K}^{\mathrm{d}}$-derived peptides could mediate linked suppression of responses to other d-haplotype alloantigens, full haplotype mismatched Dba/2 skin grafts $\left(\mathrm{H}-2^{\mathrm{d}}\right)$ were applied to $\mathrm{H}-2 \mathrm{~K}^{\mathrm{d}}$-tolerant $\mathrm{C} 57 \mathrm{BL} / 6$ mice that had accepted B6.Kd skin grafts for more than 100 days following AAV-K $\mathrm{K}^{\mathrm{d}}$ inoculation, or to naive $\mathrm{C} 57 \mathrm{BL} / 6$ recipients. No survival prolongation was observed in $\mathrm{H}-2 \mathrm{~K}^{\mathrm{d}}$-tolerant mice (Supplemental Figure 9).

\section{Discussion}

In this study, we have demonstrated that tolerance of allogeneic MHC class I can be induced in several different donor-recipient strain combinations by AAV-mediated gene transfer to hepatocytes and that recognition of intact donor $\mathrm{MHC}$ class I molecules by alloreactive $\mathrm{CD} 8^{+} \mathrm{T}$ cells is a requirement for tolerance induction. In accordance with data from a number of other studies (19, 40-42), tolerance induction is dependent upon the expression of high levels of the donor MHC class I in recipient hepatocytes. The vector dose required to achieve tolerance was $5 \times 10^{11} \mathrm{vgc}, 10$-fold higher than the dose of AAV-K required to achieve indefinite survival in the majority of naive B10.BR mice in an earlier study (19), despite uniform strong expression of $\mathrm{K}^{\mathrm{d}}$ on the surface of all hepatocytes across the liver lobule at the lower dose of $5 \times 10^{10} \mathrm{vgc}$. The reasons for this difference are unclear but may relate to a higher precursor frequency of $\mathrm{K}^{\mathrm{d}}$-reactive $\mathrm{T}$ cells in $\mathrm{C} 57 \mathrm{BL} / 6$ recipients compared with the frequency of $\mathrm{K}^{\mathrm{b}}$-reactive cells in B10.BR hosts, or to more rapid turnover of hepatocytes in C57BL/6, leading to the loss of 
A

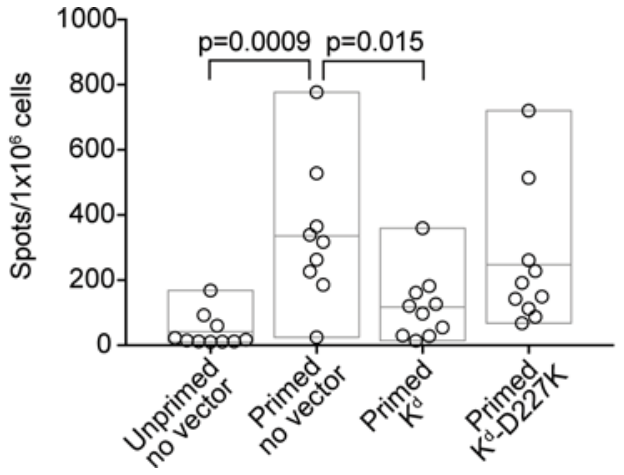

B

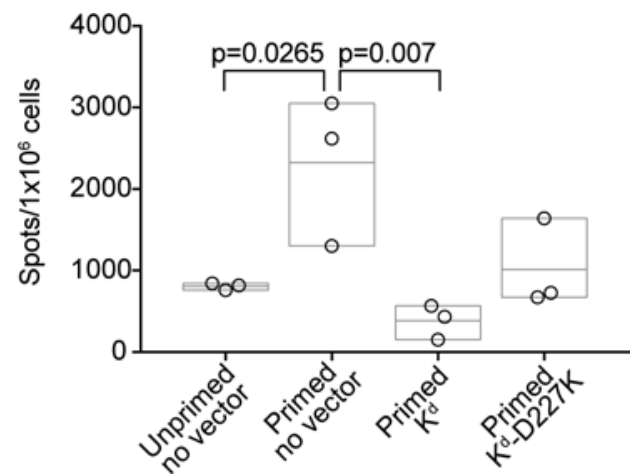

Figure 7. IFN- $\gamma$ production by alloreactive responder cells is reduced by recognition of intact but not processed MHC class I. (A) Anti- $K^{d}$ alloresponses were estimated using IFN- $\gamma$ ELISpot. C57BL/6 mice were primed against $K^{d}$ by rejection of a B6.Kd skin graft. Thirty to 35 days later, some mice were injected with $5 \times 10^{11} \mathrm{vgc} \mathrm{AAV-Kd}$ or $\mathrm{K}^{\mathrm{d}-}$ D227K. After a further 7 days, splenocytes from inoculated mice, primed mice that were not inoculated with vector, or unprimed C57BL/ 6 controls ( $n=9-10 /$ group) were prestimulated in a 1-way multiple linear regression (MLR) with irradiated B6.Kd splenocytes, and IFN- $\gamma$-producing cells were enumerated using ELISpot. (B) Statistical analysis was performed using 1-way ANOVA in conjunction with Sidak's multiple comparisons test. The number of responder cells producing IFN- $\gamma$ in response to $\mathrm{K}^{\mathrm{d}}$-bearing stimulators increased from $41.78 \pm 16.45$ spot-forming cells/

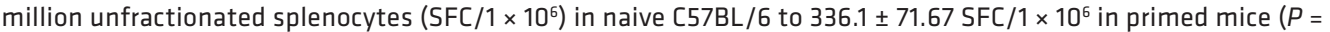
$0.0009)$. Inoculation of primed $\mathrm{C57BL} / 6$ mice with AAV- $\mathrm{K}^{\mathrm{d}}$ significantly decreased IFN- $\gamma$ production $(117.4 \pm 32.63$ $\mathrm{SFC} / 1 \times 10^{6}, P=0.015$ compared with primed mice not receiving vector), while treatment with AAV-K ${ }^{\mathrm{d}}-\mathrm{D} 227 \mathrm{~K}$ did not reduce the anti- $K^{d}$ response $\left(247.4 \pm 66.33 \mathrm{SFC} / 1 \times 10^{6}, P=0.55\right)$. Parallel results were obtained when pooled, CD8-enriched splenocytes from primed mice were used as responders $(n=3 /$ group). Results were analyzed as for A. CD8-enriched splenocytes from unprimed C57BL/6 mice contained $807.6 \pm 23.84 \mathrm{SFC} / 1 \times 10^{6}$, while 2,324 \pm 525.8 $\mathrm{SFC} / 1 \times 10^{6}$ were detected in the primed animals $(P=0.0265)$. In primed mice transduced with AAV- $\mathrm{K}^{\mathrm{d}}$, the number of IFN- $\gamma$-producing cells fell to $384.4 \pm 122 \mathrm{SFC} / 1 \times 10^{6}(P=0.007)$, whereas a nonsignificant reduction was noted when primed mice received AAV- $K^{\mathrm{d}}-\mathrm{D} 227 \mathrm{~K}\left(1,014 \pm 313.5 \mathrm{SFC} / 1 \times 10^{6}, P=0.053\right)$. Box shows minimum to maximum with a line at the mean. All data are described as mean \pm SEM.

episomal AAV vector genomes. Gene transfer to recipient liver using AAV vectors is an emerging therapy for the induction of antigen-specific tolerance (16), which could be of significant benefit in the setting of clinical organ and tissue transplantation. A broad array of mismatched MHC antigens may be encountered by recipients, and so establishing the generalizability of this approach beyond the strain combination where it was initially demonstrated is a prerequisite for further progress toward clinical translation. Understanding the mechanisms that contribute to tolerance induction is essential to facilitate refinement and optimization of tolerance-induction protocols. Moreover, insights gained from the study of responses to allogeneic MHC transgenes expressed in the liver may enhance our understanding of related phenomena such as spontaneous liver transplant tolerance.

Multiple pathways for donor antigen presentation may be active following transduction of recipient hepatocytes with donor MHC class I. Intact allogeneic class I expressed on the hepatocyte surface may be directly recognized by recipient $\mathrm{CD} 8^{+} \mathrm{T}$ cells. Semidirect recognition may follow the transfer of intact donor class I from hepatocytes to the surface of other cell types (43-45). Peptides derived from the allogeneic class I protein may be presented to self-restricted $\mathrm{CD}^{+} \mathrm{T}$ cells associated with $\mathrm{MHC}$ class I of the recipient haplotype (46), either on hepatocytes (indirect recognition) or on other APC (cross-presentation). Cross-presentation in the liver is restricted to liver sinusoidal endothelial cells and some liver DC subsets $(26,27)$, and in the absence of inflammation, it is generally associated with tolerance induction $(27,47-49)$. Presentation of donor class I peptides by recipient MHC class II to recipient $\mathrm{CD} 4^{+} \mathrm{T}$ cells (indirect recognition) may also occur (50). We took advantage of a point mutation that abrogates CD8 coreceptor binding and, thus, interferes with recognition of the intact donor MHC class I (35) - but does not prevent peptide processing and presentation - to examine the contributions of intact and processed MHC class I to transplant tolerance induction.

In both B10.BR and C57BL/6 strains, impairment of direct or semi-direct recognition of intact donor MHC class I by introduction of the D227K mutation prevented tolerance induction. Recognition of processed donor MHC class I alone yielded a modest survival prolongation in both strain combinations, attributable to the generation of $\mathrm{CD} 4^{+}$Tregs. However, depletion of Tregs in the presence 


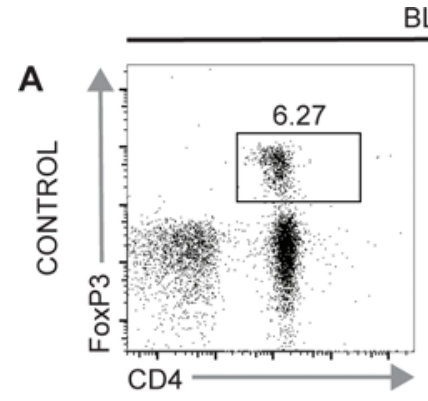

BLOOD
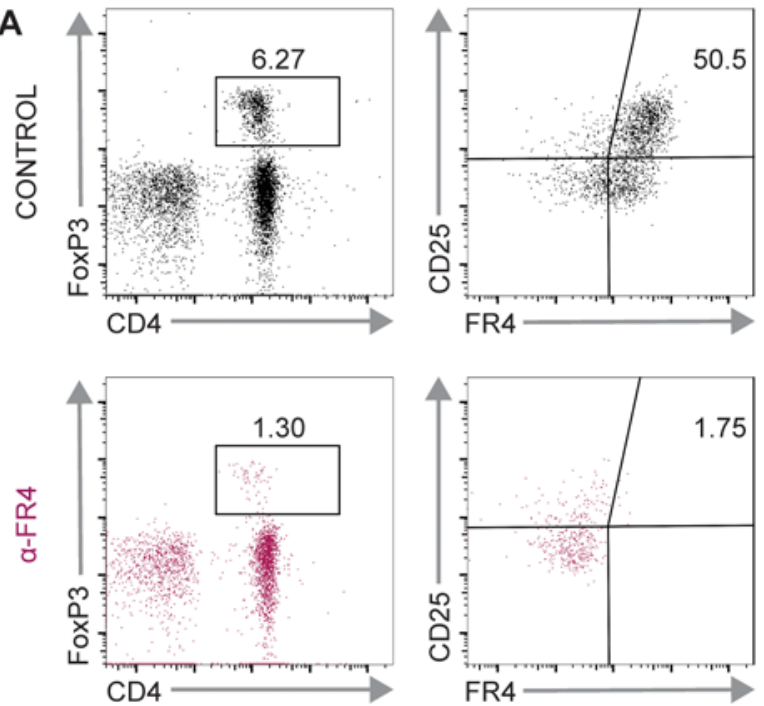

BLOOD

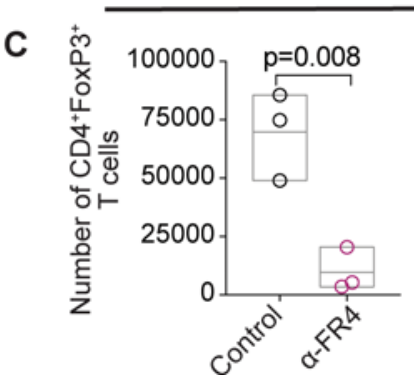

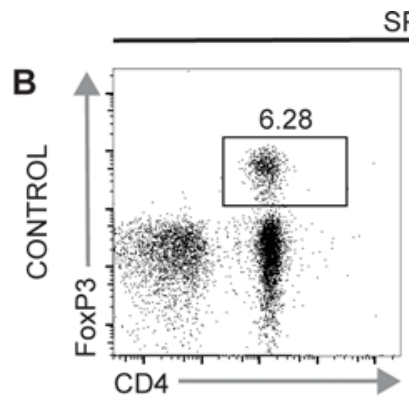

SPLEEN
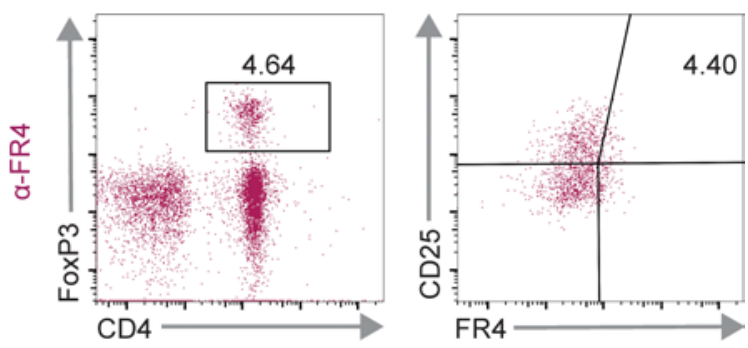

FR4

\section{SPLEEN}

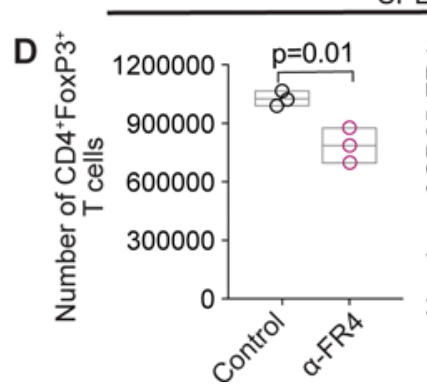

Figure 8. A monoclonal antibody against FR4 reduces Treg numbers in peripheral blood and spleen. Administration of the anti-FR4 monoclonal antibody TH6 $(100 \mu \mathrm{g})$, i.v., was used to deplete the population of CD4+ Tregs from B10.BR mice. The nondepleting anti-FR4 antibody 12 A5 does not compete for epitope binding against TH6 (Supplemental Figure 6) and was used for FR4 detection. TH6 treatment significantly reduced the

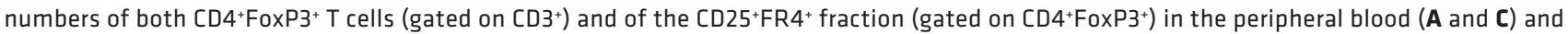
spleen (B and D) of B10.BR mice at 24 hours after injection. CD4+FoxP3 ${ }^{+}$T cells in peripheral blood declined substantially from $6.98 \times 10^{4} \pm 9.72 \times 10^{3}$ in controls to $1.09 \times 10^{4} \pm 5.38 \times 10^{3}$ in TH6-treated mice $(C)(P=0.008)$, while a lesser reduction in $\mathrm{CD}^{+} \mathrm{FoxP} 3^{+} \mathrm{T}$ cells $\left(\right.$ from $1.03 \times 10^{6} \pm 2.19 \times 10^{4}$ to $\left.7.86 \times 10^{5} \pm 5.17 \times 10^{4}, P=0.01\right)$ was detected in the spleen (D). CD25+FR4 ${ }^{+} \mathrm{T}$ cells in peripheral blood decreased from $3.45 \times 10^{4} \pm 5.59 \times 10^{3}$ to $216 \pm$ $131(P=0.0036)$ following anti-FR4 administration $(C)$, whereas in spleen, the reduction in CD25+FR4 ${ }^{+} \mathrm{T}$ cells was from $3.86 \times 10^{5} \pm 7.75 \times 10^{3}$ to 3.42 $\times 10^{4} \pm 3.02 \times 10^{3}, P<0.0001$. While decline of the FR4 ${ }^{+}$fraction in spleen was accompanied by an overall reduction in CD4+FoxP3 ${ }^{+}$cell numbers, there was also an increase in the proportion of CD25+FR4- cells upon TH6 treatment (B), suggesting that FR4 engagement may have resulted in shedding or internalization of this receptor on some cells. $n=3$ /group for all experiments. A and $\mathbf{B}$ show representative flow plots. In $\mathbf{C}$ and $\mathbf{D}$, box shows minimum to maximum with a line at the mean. Data are described as mean \pm SEM, and statistical analyses were performed using an unpaired $t$ tests.

of direct recognition of donor MHC class I did not alter graft survival, in contrast to several other models of tolerance induction following gene transfer to liver, where $\mathrm{CD} 4^{+}$Tregs are critical mediators of tolerance (9-12). Activation (and subsequent regulatory conversion) of $\mathrm{CD}^{+} \mathrm{T}$ cells by peptides derived from these cytosolic or secreted transgene products may form a more prominent component of the recipient immune response than in our model where the transgene product is an allogeneic MHC class I molecule expressed on the cell surface.

Reported outcomes of primary $\mathrm{CD}^{+} \mathrm{T}$ cell activation in liver in the presence of a moderate or large antigen load include deletion (by suicidal emperipolesis or apoptosis; refs. 51-53), exhaustion, and functional silencing $(19,41,53)$ or the development of a regulatory phenotype $(54)$. CD $8^{+}$Tregs generated in response to AAV-mediated expression of $\mathrm{H}-2 \mathrm{~K}^{\mathrm{d}}$ in hepatocytes were able to mediate acceptance of allogeneic pancreatic islet grafts following adoptive transfer into naive, immunocompetent recipients (54). The fate of $\mathrm{CD}^{+} \mathrm{T}$ cells activated through direct recognition by allogeneic $\mathrm{MHC}$ 


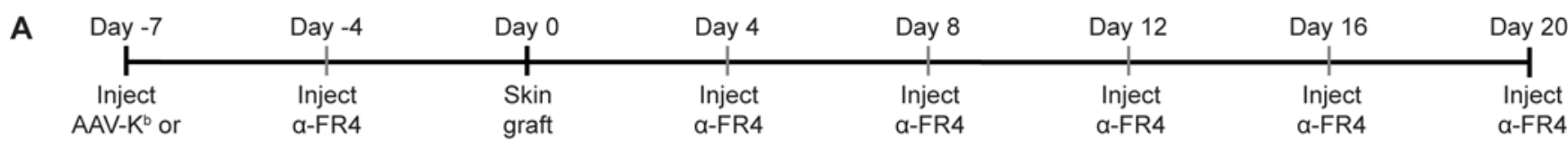

$K^{b}-\mathrm{D} 227 \mathrm{~K}$

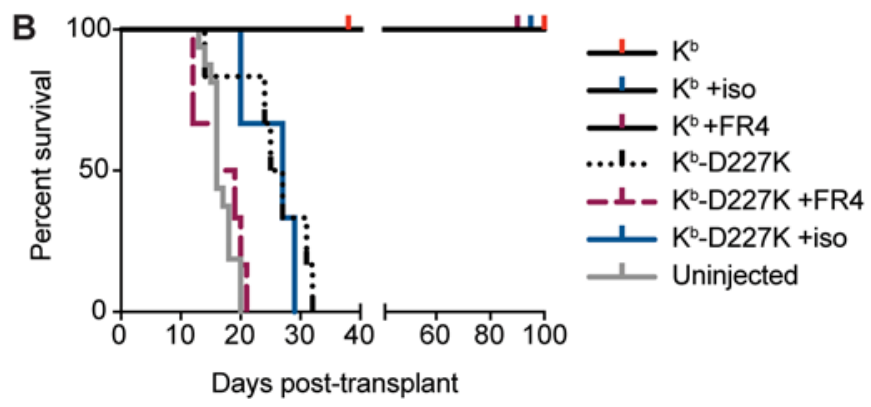

Figure 9. Depletion of CD4+ ${ }^{+}$Tregs blocks prolongation of $\mathbf{K}^{\mathbf{b}}$-bearing skin graft survival by AAV-K $\mathbf{K}^{\mathbf{b}}-\mathbf{D} 227 \mathrm{~K}$. B10.BR mice inoculated with either AAV-K ${ }^{\mathrm{b}}$ or $\mathrm{K}^{\mathrm{b}}$-D227K $\left(5 \times 10^{11} \mathrm{vgc}\right) 7$ days prior to a $\mathrm{K}^{\mathrm{b}}$-bearing 178.3 skin graft received i.v. injections of $100 \mu \mathrm{g}$ TH6 or isotype control mAb every 4 days between $\mathrm{d}-4$ and d20 (A). Skin graft survivals (B) were compared using the logrank test. Skin grafts to B10.BR mice transduced with AAV-K ${ }^{b}$ survived indefinitely, irrespective of the coadministration of anti-FR4 $(n=4)$ or isotype control antibody $(n=4)$, as did syngeneic grafts (not shown). Conversely, the survival prolongation obtained through treatment of recipient mice with AAV-K $\mathrm{K}^{\mathrm{b}}-\mathrm{D} 227 \mathrm{~K}$ (MST 26 days, compared with 16 days in untransduced mice, $P=0.015$ ) was maintained when the isotype control mAb was coadministered (MST 27 days; $n=3$ ) but abolished when anti-FR4 was given (MST 17.5 days; $n=6 ; P=0.0046$ ).

class I expressed in hepatocytes has not been determined in this study. High frequencies of PD $-1^{+} \mathrm{CD} 8^{+}$ $\mathrm{T}$ cells were detected in mice inoculated with $\mathrm{AAV}-\mathrm{K}^{\mathrm{d}}$ (but not AAV-K $\mathrm{K}^{\mathrm{d}} \mathrm{D} 227 \mathrm{~K}$ ), consistent with the findings of other recent studies $(53,54)$. Whether this denotes exhaustion, regulatory potential, or any other aspect of $\mathrm{T}$ cell function has yet to be established for this model. IFN- $\gamma$ production by both unfractionated and CD8-enriched splenocytes upon exposure to $\mathrm{H}-2 \mathrm{~K}^{\mathrm{d}}$-bearing stimulator cells was significantly reduced in mice inoculated with $A A V-K^{d}$ but not those treated with AAV-K $-\mathrm{D} 227 \mathrm{~K}$. While reduced ability to secrete IFN- $\gamma$ upon stimulation is a hallmark of T cell exhaustion, it is also possible that many alloreactive $\mathrm{CD} 8^{+} \mathrm{T}$ cells have been deleted from the responding population and/ or that the actions of $\mathrm{CD}^{+}$and $\mathrm{CD}^{+}$Tregs may have contributed to this outcome. Moreover, while hepatocytes are certainly capable of activating naive $\mathrm{CD} 8^{+} \mathrm{T}$ cells, it is not certain whether or not $\mathrm{CD}^{+} \mathrm{T}$ cells may also be activated by other APC, consequent upon cell-to-cell transfer of intact allogeneic MHC from transduced hepatocytes, and what the significance of this might be. Unlike the findings of Le Guen et al. (54), but in accordance with our previous observations (19), tolerance to a single mismatched $\mathrm{MHC}$ antigen $\left(\mathrm{H}-2 \mathrm{~K}^{\mathrm{d}}\right)$ did not confer tolerance to a subsequent full haplotype mismatched skin graft from $\mathrm{Dba} / 2\left(\mathrm{H}-2^{\mathrm{d}}\right)$ donors. In this respect, skin graft rejection may be more difficult to overcome than islet rejection, or the lower dose of AAV- $\mathrm{K}^{\mathrm{d}}$ vector used by Le Guen and colleagues (54) $\left(1.2 \times 10^{12} \mathrm{vgc} / \mathrm{kg}\right.$ compared with the dose of approximately $2 \times 10^{13} \mathrm{vgc} / \mathrm{kg}$ required to achieve skin graft tolerance in the current study) may have favored the emergence of a regulatory phenotype rather than deletion or silencing.

In conclusion, recognition of intact $\mathrm{MHC}$ class I by alloreactive $\mathrm{CD} 8^{+} \mathrm{T}$ cells is required for tolerance induction via liver-directed expression of donor MHC class I. Indirect recognition of class I allopeptides and generation of Tregs can produce a modest prolongation of class I-mismatched skin graft survival but does not induce tolerance. These findings have significant implications for the development of strategies to induce transplant tolerance in the clinic. Future approaches that might increase the generation of $\mathrm{CD}^{+}$Tregs while maintaining the potent induction of tolerance in alloreactive $\mathrm{CD} 8^{+} \mathrm{T}$ cell populations might include coadministration of soluble with surface-expressed MHC class I to increase uptake of the allogeneic MHC by class II-expressing recipient APC (12). Alternatively, allogeneic MHC class I gene transfer to hepatocytes may be combined with regulatory cell infusion protocols, such as those evaluated under the auspices of the One study (55-57) and subsequent clinical trials. 

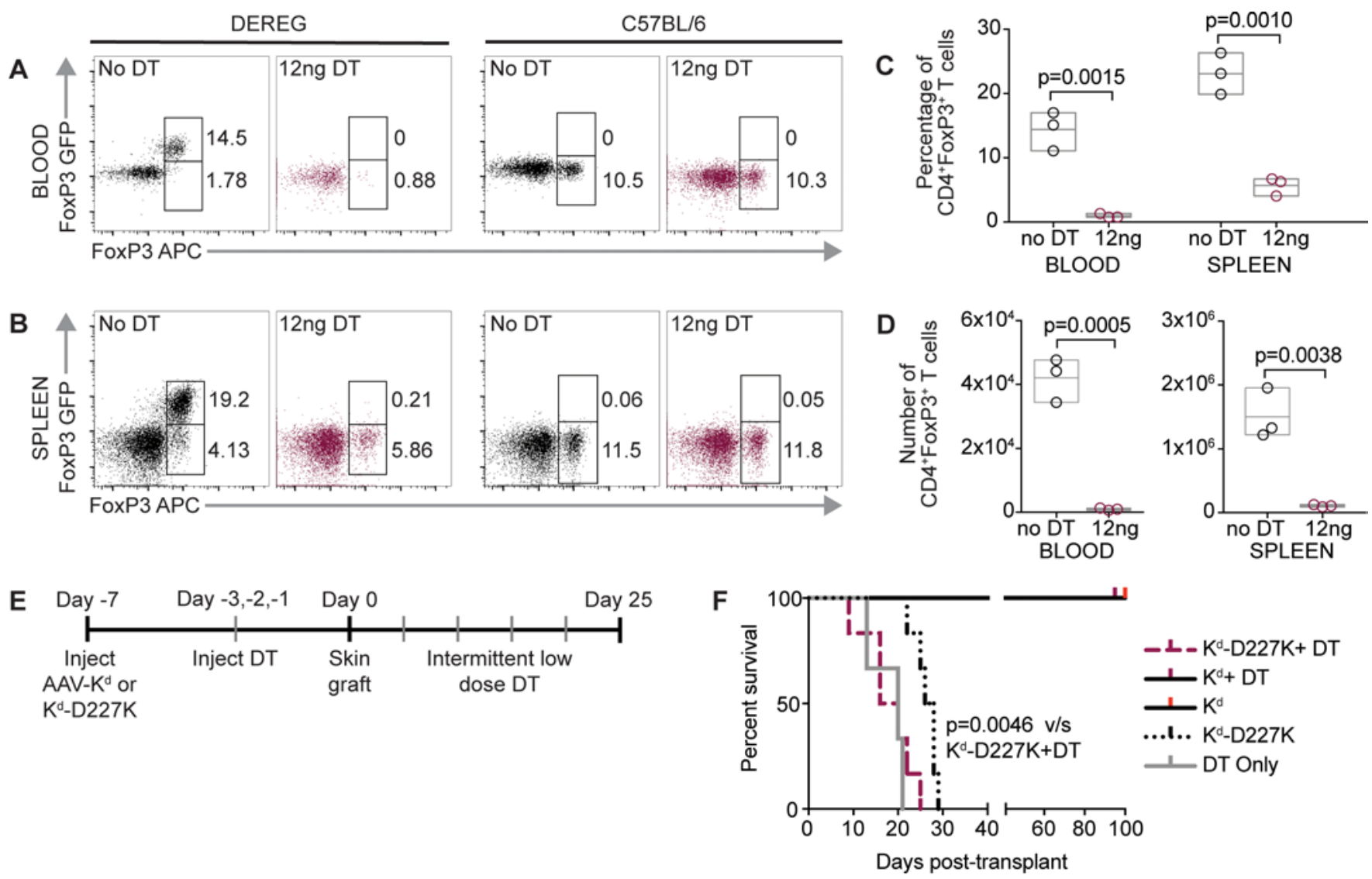

Figure 10. Depletion of CD4 ${ }^{+}$FoxP3 ${ }^{+}$Tregs abrogates the survival prolongation of $\mathbf{K}^{\mathrm{d}}$-bearing skin grafts to $\mathbf{b}$-haplotype DEREG mice. DEREC or C57BL/6 mice were treated with $12 \mathrm{ng} / \mathrm{g}$ Diphtheria toxin (DT) i.p. for 3 consecutive days, following which blood and splenocytes were collected and stained for the presence of FoxP3 ${ }^{+}$T cells. A and $\mathbf{B}$ are gated on $\mathrm{CD} 3^{+} \mathrm{CD} 4^{+}$cells and show representative plots $(n=3)$. DT administration did not alter the percentage of FoxP3 ${ }^{+}$cells in the blood (A) or spleen (B) of C57BL/6 mice. In contrast, $C D 3^{+} C D 4^{+}$T cells expressing the GFP reporter under the control of FoxP3 were almost completely absent from DT-treated DEREG mice, while a small residual population of FoxP3 ${ }^{+} \mathrm{CFP}^{-}$cells remained following depletion. $\mathbf{C}$ (gated on $\mathrm{CD}^{+} \mathrm{CD}^{+}$cells) summarizes the proportion of cells expressing FoxP3 in all DT-treated mice. In DEREG mice, FoxP3 cells declined from $14.4 \% \pm 1.7 \%$ to $0.96 \% \pm 0.19 \%$ of CD4 ${ }^{+}$T cells in blood $(P=0.015)$ and from $23.1 \% \pm 1.8 \%$ to $5.7 \% \pm 0.8 \%$ of CD4 $4^{+}$cells in spleen $(P=$ 0.010), upon DT administration. (D) Absolute numbers of $C D 4^{+} \mathrm{FoxP3}^{+} \mathrm{T}$ cells were reduced from $42,067 \pm 3,982$ to $971 \pm 192$ in the peripheral blood of DT-treated DEREG mice $(P=0.0005)$ and from $1.5 \times 10^{6} \pm 0.5 \times 10^{6}$ to $1.08 \times 10^{5} \pm 0.63 \times 10^{5}$ in spleen $(P=0.0038)$. Boxes in $\mathbf{C}$ and $\mathbf{D}$ show minimum to maximum with a line at the mean. Data described as mean \pm SEM, statistical analyses were performed using an unpaired $t$ test; $n=3 / g r o u p$. (E and F) Survival of B6.Kd skin grafts to DEREG mice transduced with AAV-Kd was not influenced by DT treatment. Conversely, B6.Kd skin graft survival in DEREG mice inoculated with AAV- $K^{\mathrm{d}}$-D227K was reduced from 27 to 18 days $(P=0.0046)$ when DT was coadministered, abrogating the survival prolongation due to expression of the $\mathrm{K}^{\mathrm{d}}$-D227K transgene. $n=6$ /group; survival analysis was performed using the log-rank test.

\section{Methods}

Mice

C57BL/6JArc $\left(\mathrm{H}-2^{\mathrm{b}}\right)$ and Dba/2JArc $\left(\mathrm{H}-2^{\mathrm{d}}\right)$ mice (termed C57BL/6 and Dba/2) were purchased from the Animal Resources Centre. DEREG $\left(\mathrm{H}-2^{b}\right)$ BAC transgenic mice express a simian DT receptorenhanced GFP (DTR-eGFP) fusion protein under control of the endogenous forkhead box P3 (FoxP3) promoter/enhancer regions on the BAC transgene (58). DEREG mice were backcrossed for 3 generations to $\mathrm{C} 57 \mathrm{BL} / 6 \mathrm{~J}$ prior to use in these experiments. B6.Kd mice (59) $\left(\mathrm{H}-2^{\mathrm{b}}\right)$ express an $\mathrm{H}-2 \mathrm{~K}^{\mathrm{d}}$ transgene ubiquitously on a C57BL/6 background. TCR75 mice are also of $\mathrm{H}-2^{\text {b }}$ haplotype and are CD 45. $1^{+/+}$. They express a transgenic TCR on $\mathrm{CD}^{+} \mathrm{T}$ cells, which recognizes the peptide QEGPEYWEEQTQRAK $\left(\mathrm{H}-2 \mathrm{~K}^{\mathrm{d}}\right.$ residues $\left.54-68\right)$ restricted by $\mathrm{I}-\mathrm{A}^{\mathrm{b}}(60,61)$. B6.Kd and TCR75 mice were originally developed by R. Pat Bucy at the University of Alabama (Tuscaloosa, Alabama, USA) and were provided by Robert Fairchild, Cleveland Clinic (Cleveland, Ohio, USA), and Anita Chong, University of Chicago (Chicago, Illinois, USA), respectively. B6.Kd mice were backcrossed for 3 generations to C57BL/6J, prior to use. TCR75-RAG mice were derived by crossing TCR75 mice with CD45.1 $1^{+/+}$ 
$\mathrm{RAG1}^{-/-}$mice (B6.SJL-Ptprca Pepcb /BoyJArc x B6.129S7-Rag1tm1Mom/ARC). DEREG, B6.Kd, and TCR75-RAG mice were bred at the University of Sydney. The 178.3 mice (originally provided by W. Heath and M. Hoffmann, Walter and Eliza Hall Institute, Melbourne, Australia) ubiquitously express transgenic $\mathrm{H}-2 \mathrm{~K}^{\mathrm{b}}$ on an $\mathrm{H}-2^{\mathrm{k}}$ haplotype background. Des-TCR mice express an $\mathrm{H}-2 \mathrm{~K}^{\mathrm{b}}-$ specific TCR identifiable by a clonotypic mAb (Désiré). Des-RAG mice were obtained by crossing DES-TCR mice with $\mathrm{H}-2^{\mathrm{k}} \mathrm{RAG} 1^{-/-}$mice. B10.BR $\left(\mathrm{H}-2^{\mathrm{k}}\right), 178.3$, and Des-RAG mice were bred at the Centenary Institute (Camperdown, Australia). Male mice aged between 8 and 12 weeks were used in these experiments. Characteristics of the different mouse strains used in this study are summarized in Supplemental Table 1.

\section{AAV vectors}

The 1107-bp coding sequence of $\mathrm{H}-2 \mathrm{~K}^{\mathrm{d}}$ was obtained from $\mathrm{Dba} / 2$ spleen complementary DNA (forward primer 5' - AGA AGT GGG CAG CTG TGG - 3'; reverse primer 5' - CTC TGG TTG TAG TAT CTC TGT GC - 3'). H-2 $\mathrm{K}^{\mathrm{b}}$ was cloned as previously described (19). H-2 $\mathrm{K}^{\mathrm{d}}$ and $\mathrm{H}-2 \mathrm{~K}^{\mathrm{b}}$ sequences incorporating the D227K mutation were created in silico and manufactured by GeneArt (Thermo Fisher Scientific). Each gene was then packaged into an AAV2/8 vector, purified, and quantitated as previously described $(19,62)$.

\section{Histology and immunostaining}

Preparation of fresh frozen sections. OCT-embedded frozen tissue blocks were cut into $6 \mu \mathrm{m}$-thick sections (using a Shandon Cryotome E, Thermo Fisher Scientific). Sections were transferred to precoated glass slides (SuperFrost, Menzel-Glazer) and allowed to air dry for 1 hour at room temperature (RT), prior to fixation in acetone for 8 minutes at RT. When dry, acetone-fixed sections were stored at $-80^{\circ} \mathrm{C}$ until further use.

IHC on frozen sections. Fresh frozen sections were thawed to RT for 15 minutes and then rehydrated by washing in tris-buffered saline (TBS). Tissue was encircled with a wax pen (Dako, catalog S2002). TBS with 20\% normal mouse serum (NMS) (MilliporeSigma, catalog M5905) and 5\% normal porcine serum (NPS) (Thermo Fisher Scientific, catalog 31890) was applied to the sections for 20 minutes to block nonspecific antibody binding. FITC-conjugated primary antibodies against $\mathrm{H}-2 \mathrm{~K}^{\mathrm{d}} \mathrm{CD} 4, \mathrm{CD} 8 \alpha, \mathrm{F} 4 / 80$, or B220 or the corresponding isotype controls (Supplemental Table 2) were diluted in TBS/5\%NPS, applied to the sections, and incubated in a humidified chamber for 30 minutes at RT. Slides were then washed twice in TBS. The secondary antibody (Supplemental Table 2) at $5 \mathrm{ng} / \mathrm{ml}$ in TBST/NMS/NPS diluent was added to the sections, which were again incubated in a humidified chamber for 30 minutes at RT. After washing in TBS, color development was achieved using diaminobenzidine (DAB) substrate chromogen system (Dako, catalog K3468). Chromogen DAB was diluted in substrate to a concentration of $50 \mu 1 / \mathrm{ml}$, applied to the sections, and incubated in a humidified chamber for 2 minutes. Slides were counterstained in Mayer's hematoxylin solution (MilliporeSigma, catalog MHS16) for 2 minutes, air-dried for 24 hours, and coverslipped using $24 \mathrm{~mm} \times 24 \mathrm{~mm}$ Deckgläser cover slips (Knittel Glass) and Fronine safety mount No.4 (Thermo Fisher Scientific, catalog FNNII068).

Processing and histochemical staining of paraffin-embedded tissue sections. Tissue processing and H\&E staining were performed by the Histopathology Laboratory, Discipline of Pathology, Sydney Medical School. Briefly, formalin-fixed tissue was paraffin-embedded, dehydrated, cleared, and infiltrated with paraffin wax before 5 $\mu \mathrm{m}$ sections were cut onto on precoated glass slides (SuperFrost, Menzel-Glazer). Fresh paraffin-embedded sections were stored at $4^{\circ} \mathrm{C}$ until further use. Before staining, precut sections were gently warmed to RT. Slides were then soaked in 3 changes of histolene for 10 minutes each, followed by rehydration of sections in graded ethanol. Finally, sections were washed in 2 changes of $\mathrm{dH}_{2} \mathrm{O}$ for 3 minutes each. Once rehydrated, the sections were kept hydrated throughout the entire staining process and not allowed to dry out.

IHC on paraffin sections. Deparaffinized and rehydrated paraffin-embedded sections were microwaved (1100W, Panasonic) in citrate buffer ( $\mathrm{pH} 6$ ) for 1 minute on $100 \%$ power and then for a further 20 minutes at $10 \%$ power for antigen retrieval. Slides were then cooled to RT and washed in TBS with $0.01 \% \mathrm{v} / \mathrm{v}$ Tween-20 (TBST; MilliporeSigma, catalog P1379). Tissue was encircled with a wax pen and then TBST with 20\% normal goat serum (NGS) (Abcam, catalog ab156046) was applied to the sections for 20 minutes. The primary antibody against mouse Ly-6B.2 or relevant isotype control (Supplemental Table 2) was diluted in TBST with $1 \%$ NGS to a concentration of $10 \mu \mathrm{g} / \mathrm{ml}$, applied to sections, and incubated in a humidified chamber for 1 hour at RT. Following incubation, slides were washed in 2 changes of TBST and then incubated with $3 \% \mathrm{H}_{2} \mathrm{O}_{2} / \mathrm{CH}_{3} \mathrm{OH}$ solution for 5 minutes at $4^{\circ} \mathrm{C}$ to block 
endogenous peroxidase activity before further washing in TBST. Sections were incubated with the secondary antibody (Supplemental Table 2) and diluted in TBST/NGS in a humidified chamber for 1 hour. Slides were washed again in TBST, followed by visualization using the Vectastain ABC kit (Vector Laboratories, catalog PK-4000), according to the manufacturer's directions. Briefly, Solution A and B were diluted in TBST/NGS to a concentration of $5 \mu 1 / \mathrm{ml}$ each, applied to the sections, and incubated in a humidified chamber for 30 minutes at RT. Color development with DAB, counterstaining, and coverslipping were performed as above.

\section{Skin transplantation}

All procedures were performed under inhalational anesthesia with isoflurane (Baxter, catalog AHN3637), 1\%$3 \%$, in oxygen at $0.5-11 / \mathrm{min}$. Tail skin was harvested by making a midline incision along the ventral aspect of the amputated tail. The skin was mobilized and separated from underlying connective tissue and then irrigated in sterile saline, flattened, and dissected to yield $6 \times 1 \mathrm{~cm}^{2}$ grafts. Grafts were stored over ice, between saline-soaked gauze impregnated with ampicillin (Alphapharm), $3 \mathrm{mg} / \mathrm{ml}$, until transplanted. Recipient mice received buprenorphine (Temgesic, Schering-Plough) $(0.05 \mathrm{mg} / \mathrm{kg}$, s.c.) for analgesia and $0.5 \mathrm{ml}$ warmed normal saline s.c. for preoperative hydration. Temperature was maintained via a Physitemp TCAT-2DF Controller (Physitemp Instruments). The back and lateral thoracic regions were shaved with a scalpel blade from the cervical to the distal thoracic levels, and they were sterilized using Chlorhexidine $0.5 \%$ in ethanol $70 \%$ (Pfizer). Two graft beds were prepared and irrigated with sterile saline. Each mouse received both a syngeneic (R) and allogeneic (L) graft. Graft edges were secured with small amounts of cyanoacrylate tissue adhesive (Dermabond, Ethicon, catalog ANX12). A nonadhesive absorptive dressing was placed on top of the graft and secured with adhesive cloth bandage. A further $0.5 \mathrm{ml}$ of warmed saline and prophylactic ampicillin (100 $\mathrm{mg} / \mathrm{kg}$ ) were administered s.c. prior to conclusion of the procedure. Skin grafts were deemed rejected when less than $20 \%$ of the graft remained. Some mice received a secondary skin graft following either rejection or long-term acceptance of the primary graft.

\section{Tissue collection}

At the termination of each experiment, tissue was collected under anesthesia. Blood was sampled via inferior vena cava (IVC) puncture, allowed to clot at RT for 60 minutes, and was then centrifuged at $1,000 \mathrm{~g}$ for 10 minutes before serum was withdrawn.

Liver was handled gently to avoid damage. The liver was divided into portions: one was formalin-fixed for 24 hours before paraffin-embedding and sectioning, and the second was embedded in OCT (Tissue-Tek, Sakura Finetec) and frozen in liquid $\mathrm{N}_{2}$ vapor, prior to storage at $-80^{\circ} \mathrm{C}$.

\section{Hepatocyte isolation}

Midline laparotomy was performed under anaesthesia; the IVC was identified. A 22 G cannula was introduced distal to the renal bifurcation and secured using a 5-0 silk tie. Retrograde perfusion of the liver was achieved via the IVC cannula. The hepatic portal vein was transected to allow outflow of perfusate. The liver was sequentially perfused with the following solutions at a flow rate of $5 \mathrm{ml} / \mathrm{min}$ (administered using a Masterflex L/S 7528-30, Thermo Fisher Scientific); firstly with $25 \mathrm{ml}$ of HBSS (Lonza, catalog 10-543F), then with $25 \mathrm{ml}$ of HBSS with $0.5 \mathrm{mM}$ EDTA (MilliporeSigma, catalog E6758), followed by 25 $\mathrm{ml}$ of HBSS, and finally with $25 \mathrm{ml}$ of HBSS plus $5 \mathrm{mM} \mathrm{CaCl}_{2}$ (calcium chloride, MilliporeSigma, catalog C5670) and $0.05 \%$ of collagenase IV (collagenase Type IV, Thermo Fisher Scientific, catalog 17104019). All solutions were warmed to $37^{\circ} \mathrm{C}$. The gall bladder was removed and discarded. Lobes of the liver were collected, taking care to avoid damage, and transferred into a Petri dish containing RPMI 1640 (Lonza, catalog $12-702 \mathrm{~F}$ ) medium with $2 \% \mathrm{FCS}$ (RPMI/FCS2) at $4^{\circ} \mathrm{C}$ and gently agitated to disperse the hepatocytes. The hepatocyte slurry was transferred to a $50 \mathrm{ml}$ conical tube and washed with RPMI/FCS2 by centrifugation at $50 \mathrm{~g}$ for 3 minutes. The hepatocyte pellet was gently resuspended in $15 \mathrm{ml}$ PBS (ambient temperature), and then $9 \mathrm{ml}$ of isotonic Percoll PLUS (GE Healthcare Life Sciences, Australia) were added and mixed. The mixture was centrifuged at $500 \mathrm{~g}$ for 15 minutes at RT with the brake off. Debris and excess solution was aspirated from the tube, and the hepatocyte pellet was washed twice, as above. Viable hepatocytes were resuspended in RPMI + 10\%FCS (RPMI/FCS10) and counted on a hemocytometer using Trypan Blue exclusion. 
Leukocyte isolation from liver, spleen, and draining $L N$

For liver leukocyte isolation, the IVC was cannulated as above. The liver was flushed with $20 \mathrm{ml}$ of PBS at RT, with venting via a portal vein incision. Liver lobes were transferred onto a $100 \mu \mathrm{m}$ cell strainer, gently pressed through and washed through with cold RMPI/FCS2, and then transferred into a $50 \mathrm{ml}$ conical tube. The liver slurry was washed twice with $50 \mathrm{ml}$ RPMI + 5\% FCS (RPMI/FCS5) by centrifugation at $400 \mathrm{~g}$ for 10 minutes. The supernatant was decanted, and the cell pellet was then resuspended in $15 \mathrm{ml}$ PBS (RT). Isotonic Percoll PLUS (9 ml)were added and mixed; tubes were centrifuged at $500 \mathrm{~g}$ for 15 minutes, with no brake. The supernatant was discarded, and the liver leucocytes were then washed once before being resuspended in $2 \mathrm{ml}$ of red cell lysis solution and left to incubate for 2 minutes. Following this, the liver leucocytes were washed twice with RPMI/FCS5 before viable cells were counted, as above. The spleen was pressed through a $70 \mu \mathrm{m}$ nylon mesh strainer into a $50 \mathrm{ml}$ conical tube, and the strainer was rinsed with $50 \mathrm{ml}$ cold RPMI/FCS5. The cells were spun at $400 \mathrm{~g}$ for 10 minutes. The supernatant was discarded, and cells were then incubated in $2 \mathrm{ml}$ of red cell lysis buffer for 2 minutes at RT. The cells were washed and counted, as above. The liver draining (hepatic portal, para-aortic, and mesenteric) LNs were identified using 10× surgical magnification and excised. The nodes were ruptured through a $40 \mu \mathrm{m}$ nylon mesh strainer and then prepared as for splenocytes, with the omission of the red cell lysis step.

\section{Adoptive transfers}

Lymphocytes were collected and processed as detailed above. They were resuspended in RPMI/FCS10 to yield $1 \times 10^{7}$ cells per $900 \mu \mathrm{l}$, and $900 \mu \mathrm{l}$ aliquots were dispensed into round-bottom polystyrene tubes. CFSE (100 $\mu$ of $100 \mu \mathrm{M}$; Thermo Fisher Scientific, catalog C34570) was added to each tube, mixed by vortex, and allowed to incubate at RT for 4 minutes. The reaction was quenched by the addition of RPMI/ FCS10. The labeled cells were pooled, washed twice with cold medium, filtered through $40 \mu \mathrm{m}$ nylon mesh, and counted. Des-RAG $\left(1 \times 10^{6}\right)$ or $1 \times 10^{7}$ TCR75-RAG cells were resuspended in $500 \mu 1$ sterile PBS for i.v. injection.

\section{Flow cytometry}

Briefly, a single-cell suspension of $1 \times 10^{6}$ leucocytes in ice-cold FACS buffer (PBS/2\% FCS) was transferred into a polystyrene round-bottom tube. The cells were blocked with $1 \mu \mathrm{g}$ mouse Fc Block (BD Biosciences, catalog 553141) for 10 minutes at $4^{\circ} \mathrm{C}$. To this, a cocktail of directly conjugated primary antibodies (Supplemental Table 2) was added and incubated for 20 minutes on ice. To determine viability, all cells were washed twice with ice-cold PBS and then incubated with Zombie NIR (BioLegend, catalog 423105) for 15 minutes at RT. For FoxP3 detection, cells were fixed and permeabilized after surface and viability staining using the anti-mouse/rat FoxP3 staining set (eBioscience, catalog 77-5775-40) and then incubated with anti-FoxP3 (FJK-15s). Alternatively, $2.5 \times 10^{5}$ hepatocytes were blocked as above and stained with 1 $\mu \mathrm{g}$ of biotin-conjugated anti-mouse $\mathrm{H}-2 \mathrm{~K}^{\mathrm{d}}$ (clones SF1-1.1 or 15-5-5S) or H-2 $\mathrm{K}^{\mathrm{b}}$ (clone B8-24-3), followed by washing and then by incubation with streptavidin-PE for 20 minutes on ice. Clones 15-5-5S and B8-243 were chosen for comparison of surface expression between the WT and mutant forms of $\mathrm{H}-2 \mathrm{~K}^{\mathrm{d}}$ or $\mathrm{K}^{\mathrm{b}}$ because they recognize determinants within the $\alpha 1$ and $\alpha 2$ but not $\alpha 3$ domains of the relevant MHC class I heavy chain $(63,64)$. For some experiments, hepatocytes were fixed and permeabilized following surface and viability staining, as above, and stained to detect the hepatocyte marker cytokeratin 8 . After 2 further washes, cells were filtered and run on an LSR Fortessa X-20 (BD Biosciences). Analysis of data was performed using FlowJo v10.

\section{Imaging flow cytometry}

Isolated C57BL/6 hepatocytes were stained with antibodies against both $\mathrm{K}^{\mathrm{d}}$ and $\mathrm{K}^{\mathrm{b}}$, as well as Zombie NIR. Hepatocytes were then run on an AMNIS ImageStream Mk II (MilliporeSigma) at 40× magnification and the low-speed setting. Imaging flow files were analyzed using IDEAS v6.2 software (MilliporeSigma).

\section{ELISpot}

IFN- $\gamma$ ELISpot assays were performed following the manufacturer's protocol (U-Cytech, catalog CT317PR5). B6.Kd and C57BL/6 mouse splenocytes were isolated and the B6.Kd stimulator cells irradiated at 15 Gy. For some assays, CD8-enriched responder splenocytes were prepared using the CD $8 \alpha^{+} \mathrm{T}$ Cell Isolation Kit and accompanying protocol (catalog 130-104-075, Miltenyi Biotec). For enrichment, unfractionated 
splenocytes were incubated with a cocktail of antibody and detection beads, and they were then separated on the autoMACS Pro Separator (Miltenyi Biotec) using the "Depletes" program. The negative fraction containing $\mathrm{CD}^{+} \mathrm{T}$ cells was washed, counted, and subsequently used for ELISpot. The fraction of CD8 ${ }^{+}$ $\mathrm{T}$ cells within the enriched splenocyte populations averaged $75 \% \pm 3.8 \%$, and $\mathrm{CD} 4^{+} \mathrm{T}$ cells were virtually undetectable following separation (Supplemental Figure 10).

For prestimulation, $1 \times 10^{6}$ of stimulator and $1 \times 10^{6}$ responder splenocytes were suspended in $250 \mu 1$ RPMI/FCS10 plus penicillin-streptomycin (Invitrogen, catalog 15140) in each well of a 96-well U-bottom plate (Corning, catalog 3788). They were cultured at $37^{\circ} \mathrm{C}+5 \% \mathrm{CO}_{2}$ in a humidified incubator for 24 hours and then transferred into an antibody-coated polyvinylidene difluoride (PVDF) plate, serially diluted, and incubated for a further 16 hours. The plates were then developed, and the spots were counted using an AID iSpot plate reader as previously described (19).

\section{Depletion studies with anti-FR4 or DT}

The anti-FR4 monoclonal antibody TH6 (65) was used to deplete Tregs from B10.BR mice. This antibody has been previously demonstrated to increase the effectiveness of antitumor vaccination, through a reduction in Treg numbers and function (66). Mice were inoculated with $5 \times 10^{11} \mathrm{vgc}$ of either AAV-K ${ }^{\mathrm{b}}$ or AAV$\mathrm{K}^{\mathrm{b}} \mathrm{D} 227 \mathrm{~K}, 7$ days prior to skin transplantation. They also received $100 \mu \mathrm{g}$ of either TH6 (clone TH6, eBioscience, catalog 16-5446-85) or the isotype control antibody Rat IgG2a $\kappa$ (clone eBr2a, eBioscience, catalog 16-4321-85) i.v. in $500 \mu \mathrm{l}$ sterile PBS on d-4, and each 4 days thereafter until d20 after transplant. Prior dose-response studies had determined that a low dose of $12 \mathrm{ng} / \mathrm{g}$ DT, administered i.p. to DEREG mice on 3 consecutive days, effectively depleted $\mathrm{CD} 4{ }^{+} \mathrm{CD} 25^{+} \mathrm{FoxP} 3^{+}$Tregs from peripheral blood, spleen, and liver (67). DEREG mice or C57BL/ 6 controls were inoculated i.v. with AAV-K ${ }^{\mathrm{d}}$ or AAV-K $-\mathrm{D} 227 \mathrm{~K}$ at $5 \times 10^{11}$ $\mathrm{vgc}$, or no vector 7 days prior to skin transplantation. Half of each group were treated with DT (Unnicked, Corynebacterium diphtheria, Merck, catalog 322326) 12 ng/g i.p. in PBS for 3 days preceding transplantation and on postoperative days $3-5,10-12,16-18$, and $23-25$, or until skin graft rejection supervened.

\section{Statistics}

Statistical analysis was performed using Prism 7.0 for Mac OS X (GraphPad Software). Survival curves were compared using the log-rank (Mantel-Cox) or Gehan-Breslow-Wilcoxon tests. Differences between 2 groups were evaluated using a 2-tailed unpaired $t$ test, while 3 or more groups were compared using 1-way ANOVA followed by Sidak's or Tukey's multiple comparisons test. For analysis of 2 variables, 2-way ANOVA was used, with additional application of Sidak's or Dunnett's multiple comparisons tests.

\section{Study approval}

All animal studies were approved by the University of Sydney Animal Ethics Committee and/or by the Animal Ethics Committee of the Sydney Local Health District.

\section{Author contributions}

AS, GAB, MPH, EC, MH, SIA, PB, and DGB designed the studies; MPH, ML, EC, DLJB, KB, SST, ZW, $\mathrm{CW}$, and CM carried out experiments and acquired data; MPH, ML, EC, DLJB, and AS analyzed data; SST, GJL, IEA, SIA, and TDS provided reagents; and MPH, ML, and AS wrote the manuscript.

\section{Acknowledgments}

This work was funded by the National Health and Medical Research Council of Australia (project grants 1029205 to AS and AB and 1086451 to PB and DGB), the Royal Prince Alfred Hospital Transplant Institute, the Sydney Medical School Foundation, the Myee Codrington Medical Research Foundation, and the Microsearch Foundation of Australia. ML received a Research Training Program Postgraduate Award (SC1999) from the Department of Education and Training, Australian Federal Government. MH was supported by an early career fellowship (1013185) from the National Health and Medical Research Council of Australia. Invaluable support was provided by the personnel of the Centenary Institute Animal Facility and of Laboratory Animal Services (the University of Sydney), as well as the Bosch Institute Molecular Biology Facility, Sydney Cytometry, and the Histopathology Facility, Discipline of Pathology, Sydney Medical School. 
Address correspondence to: Alexandra Sharland, Level 5 East, Charles Perkins Centre D17, The University of Sydney, NSW 2006 Australia. Phone: 61.2.9351.2897; Email: alexandra.sharland@sydney.edu.au.

DLJB's present address is: Department of Plastic Surgery, The Alfred Hospital, Melbourne, Australia.

SST's present address is: EMBL Australia, Single Molecule Science node, School of Medical Sciences, University of New South Wales, Sydney, NSW 2052, Australia.

1. ANZDATA Registry. 39th Report, Chapter 8: Transplantation. Australia and New Zealand Dialysis and Transplant Registry, Adelaide, Australia. 2017 . http://www.anzdata.org.au/anzdata/AnzdataReport/39thReport/c08_transplantation_ v2.0_20170418.pdf. Accessed July 12, 2018.

2. Kamada N, Davies HS, Roser B. Reversal of transplantation immunity by liver grafting. Nature. 1981;292(5826):840-842.

3. Calne RY, et al. Induction of immunological tolerance by porcine liver allografts. Nature. 1969;223(5205):472-476.

4. Benseler V, McCaughan GW, Schlitt HJ, Bishop GA, Bowen DG, Bertolino P. The liver: a special case in transplantation tolerance. Semin Liver Dis. 2007;27(2):194-213.

5. Lerut J, Sanchez-Fueyo A. An appraisal of tolerance in liver transplantation. Am J Transplant. 2006;6(8):1774-1780.

6. Farci P, et al. Lack of protective immunity against reinfection with hepatitis C virus. Science. 1992;258(5079):135-140.

7. Chisari FV, Ferrari C. Hepatitis B virus immunopathogenesis. Annu Rev Immunol. 1995;13:29-60.

8. Chisari FV, Isogawa M, Wieland SF. Pathogenesis of hepatitis B virus infection. Pathol Biol. 2010;58(4):258-266.

9. Lüth S, et al. Ectopic expression of neural autoantigen in mouse liver suppresses experimental autoimmune neuroinflammation by inducing antigen-specific Tregs. J Clin Invest. 2008;118(10):3403-3410.

10. Breous E, Somanathan S, Vandenberghe LH, Wilson JM. Hepatic regulatory T cells and Kupffer cells are crucial mediators of systemic T cell tolerance to antigens targeting murine liver. Hepatology. 2009;50(2):612-621.

11. Akbarpour M, et al. Insulin B chain 9-23 gene transfer to hepatocytes protects from type 1 diabetes by inducing Ag-specific FoxP3+ Tregs. Sci Transl Med. 2015;7(289):289ra81.

12. Perrin GQ, et al. Dynamics of antigen presentation to transgene product-specific CD4+ T cells and of Treg induction upon hepatic AAV gene transfer. Mol Ther Methods Clin Dev. 2016;3:16083.

13. Chan CC, Lai CW, Wu CJ, Chen LC, Tao MH, Kuo ML. Liver-Specific Allergen Gene Transfer by Adeno-Associated Virus Suppresses Allergic Airway Inflammation in Mice. Hum Gene Ther. 2016;27(8):631-642.

14. Asokan A, Schaffer DV, Samulski RJ. The AAV vector toolkit: poised at the clinical crossroads. Mol Ther. 2012;20(4):699-708

15. Baruteau J, Waddington SN, Alexander IE, Gissen P. Gene therapy for monogenic liver diseases: clinical successes, current challenges and future prospects. J Inherit Metab Dis. 2017;40(4):497-517.

16. Sack BK, Herzog RW, Terhorst C, Markusic DM. Development of Gene Transfer for Induction of Antigen-specific Tolerance. Mol Ther Methods Clin Dev. 2014;1:14013.

17. Kattenhorn LM, et al. Adeno-Associated Virus Gene Therapy for Liver Disease. Hum Gene Ther. 2016;27(12):947-961.

18. Lisowski L, et al. Selection and evaluation of clinically relevant AAV variants in a xenograft liver model. Nature. 2014;506(7488):382-386.

19. Cunningham EC, et al. Gene therapy for tolerance: high-level expression of donor major histocompatibility complex in the liver overcomes naive and memory alloresponses to skin grafts. Transplantation. 2013;95(1):70-77.

20. Adams AB, et al. Heterologous immunity provides a potent barrier to transplantation tolerance. J Clin Invest. 2003;111(12):1887-1895.

21. Afzali B, Lombardi G, Lechler RI. Pathways of major histocompatibility complex allorecognition. Curr Opin Organ Transplant. 2008;13(4):438-444.

22. Holz LE, Warren A, Le Couteur DG, Bowen DG, Bertolino P. CD8+ T cell tolerance following antigen recognition on hepatocytes. J Autoimmun. 2010;34(1):15-22.

23. Sumpter TL, Abe M, Tokita D, Thomson AW. Dendritic cells, the liver, and transplantation. Hepatology. 2007;46(6):2021-2031.

24. Morelli AE, Thomson AW. Tolerogenic dendritic cells and the quest for transplant tolerance. Nat Rev Immunol. 2007;7(8):610-621.

25. Sumpter TL, Lunz JG, Demetris AJ, Thomson AW. Molecular regulation of hepatic dendritic cell function and its relation to liver transplant outcome. Transplantation. 2009;88(3 Suppl):S40-S44.

26. Schurich A, et al. Distinct kinetics and dynamics of cross-presentation in liver sinusoidal endothelial cells compared to dendritic cells. Hepatology. 2009;50(3):909-919.

27. Limmer A, et al. Efficient presentation of exogenous antigen by liver endothelial cells to CD8+ T cells results in antigen-specific T-cell tolerance. Nat Med. 2000;6(12):1348-1354.

28. Winau F, et al. Ito cells are liver-resident antigen-presenting cells for activating T cell responses. Immunity. 2007;26(1):117-129.

29. Maubach G, Lim MC, Kumar S, Zhuo L. Expression and upregulation of cathepsin S and other early molecules required for antigen presentation in activated hepatic stellate cells upon IFN-gamma treatment. Biochim Biophys Acta. 2007;1773(2):219-231.

30. Sumpter TL, et al. Hepatic stellate cells undermine the allostimulatory function of liver myeloid dendritic cells via STAT3-dependent induction of IDO. J Immunol. 2012;189(8):3848-3858.

31. Dunham RM, et al. Hepatic stellate cells preferentially induce Foxp3+ regulatory T cells by production of retinoic acid. $J$ Immunol. 2013;190(5):2009-2016.

32. Warren A, Le Couteur DG, Fraser R, Bowen DG, McCaughan GW, Bertolino P. T lymphocytes interact with hepatocytes through fenestrations in murine liver sinusoidal endothelial cells. Hepatology. 2006;44(5):1182-1190.

33. Connolly JM, Hansen TH, Ingold AL, Potter TA. Recognition by CD8 on cytotoxic T lymphocytes is ablated by several substitutions in the class I alpha 3 domain: CD8 and the T-cell receptor recognize the same class I molecule. Proc Natl Acad Sci USA. 
1990;87(6):2137-2141.

34. Schott E, Ploegh HL. Mouse MHC class I tetramers that are unable to bind to CD8 reveal the need for CD8 engagement in order to activate naive CD8 T cells. Eur J Immunol. 2002;32(12):3425-3434.

35. Sharland A, Patel A, Lee JH, Cestra AE, Saidman S, Waneck GL. Genetically modified HLA class I molecules able to inhibit human NK cells without provoking alloreactive CD8+ CTLs. J Immunol. 2002;168(7):3266-3274.

36. Sharland A, Lee JH, Saidman S, Waneck GL. CD8-interaction mutant HLA-Cw3 molecules protect porcine cells from human natural killer cell-mediated antibody-dependent cellular cytotoxicity without stimulating cytotoxic T lymphocytes. Transplantation. 2003;76(11):1615-1622.

37. Schnell MA, Hardy C, Hawley M, Propert KJ, Wilson JM. Effect of blood collection technique in mice on clinical pathology parameters. Hum Gene Ther. 2002;13(1):155-161.

38. Guimezanes A, et al. Identification of endogenous peptides recognized by in vivo or in vitro generated alloreactive cytotoxic $\mathrm{T}$ lymphocytes: distinct characteristics correlated with CD8 dependence. Eur J Immunol. 2001;31(2):421-432.

39. Bianchi E, Doe B, Goulding D, Wright GJ. Juno is the egg Izumo receptor and is essential for mammalian fertilization. Nature 2014;508(7497):483-487.

40. Wuensch SA, Pierce RH, Crispe IN. Local intrahepatic CD8+ T cell activation by a non-self-antigen results in full functional differentiation. J Immunol. 2006;177(3):1689-1697.

41. Tay SS, et al. Antigen expression level threshold tunes the fate of CD8 T cells during primary hepatic immune responses. Proc Natl Acad Sci USA. 2014;111(25):E2540-E2549.

42. Sharland A, Logan GJ, Bishop A, Alexander IE. Liver-directed gene expression using recombinant AAV 2/8 vectors--a tolerogenic strategy for gene delivery? Discov Med. 2010;9(49):519-527.

43. Smyth LA, Herrera OB, Golshayan D, Lombardi G, Lechler RI. A novel pathway of antigen presentation by dendritic and endothelial cells: Implications for allorecognition and infectious diseases. Transplantation. 2006;82(1 Suppl):S15-S18.

44. Smyth LA, Afzali B, Tsang J, Lombardi G, Lechler RI. Intercellular transfer of MHC and immunological molecules: molecular mechanisms and biological significance. Am J Transplant. 2007;7(6):1442-1449.

45. Smyth LA, Lechler RI, Lombardi G. Continuous Acquisition of MHC:Peptide Complexes by Recipient Cells Contributes to the Generation of Anti-Graft CD8+ T Cell Immunity. Am J Transplant. 2017;17(1):60-68.

46. Picarda E, et al. MHC-derived allopeptide activates TCR-biased CD8+ Tregs and suppresses organ rejection. J Clin Invest. 2014;124(6):2497-2512.

47. Kurts C, Heath WR, Kosaka H, Miller JF, Carbone FR. The peripheral deletion of autoreactive CD8+ T cells induced by cross-presentation of self-antigens involves signaling through CD95 (Fas, Apo-1). J Exp Med. 1998;188(2):415-420.

48. Berg M, et al. Cross-presentation of antigens from apoptotic tumor cells by liver sinusoidal endothelial cells leads to tumor-specific CD8+ T cell tolerance. Eur J Immunol. 2006;36(11):2960-2970.

49. Schurich A, et al. Dynamic regulation of CD8 T cell tolerance induction by liver sinusoidal endothelial cells. J Immunol. 2010;184(8):4107-4114

50. Tay SS, et al. Intrahepatic activation of naive CD4+ T cells by liver-resident phagocytic cells. J Immunol. 2014;193(5):2087-2095.

51. Benseler V, et al. Hepatocyte entry leads to degradation of autoreactive CD8 T cells. Proc Natl Acad Sci USA. 2011;108(40):16735-16740.

52. Faust SM, Bell P, Zhu Y, Sanmiguel J, Wilson JM. The role of apoptosis in immune hyporesponsiveness following AAV8 liver gene transfer. Mol Ther. 2013;21(12):2227-2235.

53. Kumar SRP, Hoffman BE, Terhorst C, de Jong YP, Herzog RW. The Balance between CD8+ T Cell-Mediated Clearance of AAV-Encoded Antigen in the Liver and Tolerance Is Dependent on the Vector Dose. Mol Ther. 2017;25(4):880-891.

54. Le Guen V, et al. Alloantigen gene transfer to hepatocytes promotes tolerance to pancreatic islet graft by inducing CD8+ regulatory T cells. J Hepatol. 2017;66(4):765-777.

55. Lee K, Nguyen V, Lee KM, Kang SM, Tang Q. Attenuation of donor-reactive T cells allows effective control of allograft rejection using regulatory T cell therapy. Am J Transplant. 2014;14(1):27-38.

56. Safinia N, Leech J, Hernandez-Fuentes M, Lechler R, Lombardi G. Promoting transplantation tolerance; adoptive regulatory T cell therapy. Clin Exp Immunol. 2013;172(2):158-168.

57. Tang Q, Bluestone JA. Regulatory T-cell therapy in transplantation: moving to the clinic. Cold Spring Harb Perspect Med. 2013;3(11).

58. Lahl K, et al. Selective depletion of Foxp3+ regulatory T cells induces a scurfy-like disease. J Exp Med. 2007;204(1):57-63.

59. Honjo K, Yan Xu X, Kapp JA, Bucy RP. Evidence for cooperativity in the rejection of cardiac grafts mediated by CD4 TCR Tg T cells specific for a defined allopeptide. Am J Transplant. 2004;4(11):1762-1768.

60. Honjo K, Xu XY, Bucy RP. Heterogeneity of T cell clones specific for a single indirect alloantigenic epitope (I-Ab/H-2Kd54-68) that mediate transplant rejection. Transplantation. 2000;70(10):1516-1524.

61. Honjo K, Xu Xy, Bucy RP. CD4+ T-cell receptor transgenic T cells alone can reject vascularized heart transplants through the indirect pathway of alloantigen recognition. Transplantation. 2004;77(3):452-455

62. Cunningham SC, Dane AP, Spinoulas A, Logan GJ, Alexander IE. Gene delivery to the juvenile mouse liver using AAV2/8 vectors. Mol Ther. 2008;16(6):1081-1088

63. Hämmerling GJ, Rüsch E, Tada N, Kimura S, Hämmerling U. Localization of allodeterminants on $\mathrm{H}$-2Kb antigens determined with monoclonal antibodies and H-2 mutant mice. Proc Natl Acad Sci USA. 1982;79(15):4737-4741.

64. Arnold B, Horstmann U, Kuon W, Burgert HG, Hämmerling GJ, Kvist S. Alloreactive cytolytic T-cell clones preferentially recognize conformational determinants on histocompatibility antigens: analysis with genetically engineered hybrid antigens. Proc Natl Acad Sci USA. 1985;82(20):7030-7034.

65. Yamaguchi T, et al. Control of immune responses by antigen-specific regulatory $\mathrm{T}$ cells expressing the folate receptor. Immunity. 2007;27(1):145-159.

66. Liang SC, Moskalenko M, Van Roey M, Jooss K. Depletion of regulatory T cells by targeting folate receptor 4 enhances the potency of a GM-CSF-secreting tumor cell immunotherapy. Clin Immunol. 2013;148(2):287-298.

67. Hu M, et al. Infiltrating Foxp3(+) regulatory T cells from spontaneously tolerant kidney allografts demonstrate donor-specific tolerance. Am J Transplant. 2013;13(11):2819-2830. 